$5-1-2020$

\title{
Police Sexual Violence: Police Brutality, \#MeToo, and Masculinities
}

Dara Purvis

Penn State Law

Melissa Blanco

Follow this and additional works at: https://elibrary.law.psu.edu/fac_works

\section{Recommended Citation}

Dara Purvis and Melissa Blanco, Police Sexual Violence: Police Brutality, \#MeToo, and Masculinities, 108 Cal. L. Rev. 1487 (2020).

This Article is brought to you for free and open access by the Faculty Works at Penn State Law eLibrary. It has been accepted for inclusion in Journal Articles by an authorized administrator of Penn State Law eLibrary. For more information, please contact ram6023@psu.edu. 


\title{
Police Sexual Violence: Police Brutality, \#MeToo, and Masculinities
}

\author{
Dara E. Purvis* and Melissa Blanco**
}

\begin{abstract}
A woman alleges that she was raped by a police officer while in police custody. The police officer acknowledges that he had sexual intercourse with the woman but argues that she consented to the interaction. Despite the clear power imbalance and troubling context of the sexual activity, in a majority of U.S. states, if the police officer convinces even one member of a jury that their activity was consensual, then the officer cannot be convicted. Consent is a defense to allegations of sexual assault - even when the alleged assault occurs while the victim is in the custody of the perpetrator.
\end{abstract}

Allegations that police officers have committed sexual assault while on duty are shockingly prevalent and surprisingly underanalyzed. Police sexual violence (PSV) is situated at the intersection of two vital national conversations about police brutality and sexual violence and harassment. This Article addresses PSV as the product of both issues and recommends systemic solutions sounding in both debates.

DOI: https://doi.org/10.15779/Z38XD0QZ2V

Copyright (C) 2020 Dara E. Purvis and Melissa Blanco.

* Professor, Penn State Law; Yale Law School, J.D.; University of Cambridge, M.Phil.; University of Southern California, B.A. Thanks to Frank Rudy Cooper, Kit Kinports, Ann McGinley, Andrea Ritchie, Theresa Rocha Beardall, Daniel E. Walters, Justin Weinstein-Tull, and participants in the UNC School of Law faculty workshop for thoughtful feedback.

** The Pennsylvania State University, Penn State Law, J.D.; University of Florida, B.A. Thank you to Professor Dara Purvis for encouraging me and rooting for me in every aspect of my law school career and specifically for pushing me to keep researching, analyzing, and writing about the human rights issues that mean the most to me. Thank you, also, to my parents, Rolando and Loretta Blanco, and my two brothers, Carlos and Brandon Blanco, who let me bounce ideas off them at all hours of the night. 
The immediate problem PSV presents is that it is not made clearly illegal by state law and police department regulation. The deeper problem is that PSV is a symptom of broader cultural problems within police departments that can be helpfully parsed through the lens of masculinities theories. PSV springs from issues both with how police officers relate to the communities they patrol, especially men in those communities, and with how police officers and police culture treat women. The famous "blue wall of silence," ensuring loyalty even among police officers who commit misconduct, magnifies these issues. Any attempt to meaningfully address PSV must take all of these factors into account to work both a legal and a cultural change. This Article offers such solutions, addressing substantive and procedural prohibitions of PSV and broader cultural changes to police departments to combat PSV at its roots.

Introduction 1489

I. The Epidemic of PSV

A. Defining PSV

B. Prevalence of PSV 1494

C. Current Laws Prohibiting PSV and an Introduction to the Power Dynamic 1498

1. The Power Dynamic: Law Enforcement Officers and "Consenting" Civilians in Custody . 1502

2. Police Departments' Policies (or Lack Thereof) Addressing PSV

II. PSV, "Boys Will Be Boys," and The Blue Wall ............................ 1511

A. Hegemonic Masculinity ................................................ 1511

B. Police Culture and Masculinities ...................................... 1513

III. A Systemic Problem Demands Systemic Reform ......................... 1519

A. The Substance of PSV: Custody and Consent .................. 1521

B. Formalities of Fighting PSV ........................................ 1524

C. Fighting the Culture of PSV ......................................... 1526

1. Call It What It Is: PSV Is a Form of Police Brutality.. 1526

2. Acknowledge PSV's Intersectionality....................... 1527

3. Changing Police Culture........................................... 1528

Conclusion 1529 


\section{INTRODUCTION}

In October 2017, two New York City police officers, Eddie Martins and Richard Hall, were charged with kidnapping and raping Anna Chambers, ${ }^{1}$ an eighteen-year-old woman whom the officers had taken into custody. ${ }^{2}$ Chambers was sitting in a parked car around 7:30 to 8:00 at night with two male friends when the two police officers pulled up in a van. ${ }^{3}$ The two police officers flashed their badges as they approached Chambers and her two friends. ${ }^{4}$ The police officers handcuffed Chambers, but told her friends that they were "free to go." Chambers recounted that the police officers took her into the van and each raped her while she was handcuffed and crying. ${ }^{6}$ About an hour later, the police officers dropped Chambers off near the area where they picked her up. ${ }^{7}$ Shortly after, Chambers and her mother went to a hospital where a nurse conducted a rape kit. ${ }^{8}$ The rape kit matched Martins's and Hall's DNA. ${ }^{9}$

In January 2016, former Oklahoma City police officer Daniel Holtzclaw was sentenced to 263 years in prison for raping and assaulting eight women of color who reported that Holtzclaw sexually assaulted them between December 2013 and June 2014. ${ }^{10}$ Another five women also reported similar assaults for which Holtzclaw was not convicted. ${ }^{11}$ One characteristic offense took place on June 17, 2014, when Holtzclaw stopped and questioned a seventeen-year-old Black woman for unknown reasons. ${ }^{12}$ After questioning her, Holtzclaw learned that the teenager had an outstanding arrest warrant for trespassing and reportedly told her to "take care of it before she turned 18 years old." ${ }^{13}$ Later that day,

1. This is not her real name, but this is the name she goes by on social media. See Albert Samaha, An 18-Year-Old Said She Was Raped While in Police Custody. The Officers Say She Consented., BUZZFEED NEws (Feb. 7, 2018), https://www.buzzfeed.com/albertsamaha/this-teenageraccused-two-on-duty-cops-of-rape-she-had-no [https://perma.cc/LW4Y-CZKQ].

2. Editorial, Close the Police Rape Loophole, N.Y. TIMES, Feb. 13, 2018, at A20, https://www.nytimes.com/2018/02/12/opinion/police-rape-loophole.html [https://perma.cc/A2H2B9B7].

3. See Samaha, supra note 1.

4. See id.

5. See id.

6. See id.

7. See id.

8. See id.

9. See id.

10. See NAACP Legal Def. \& Educ. Fund, LDF Urges Systemic Reforms to Eliminate Police Sexual Misconduct Following Sentencing of Daniel Holtzclaw, Former Oklahoma Police Officer, LEGAL DEF. FUND (Jan. 22, 2016), https://www.naacpldf.org/press-release/ldf-urges-systemic-reformsto-eliminate-police-sexual-misconduct-following-sentencing-of-daniel-holtzclaw-former-oklahomapolice-officer/ [https://perma.cc/SX6W-RXCM]; see also Kyle Schwab, Last Accuser Tells Jurors Former Police Officer Raped Her on Mom 's Porch in Northwest Oklahoma City, THE OKLAHOMAN (Dec. 1, 2015), http://newsok.com/article/5464087 [https://perma.cc/DY4V-PSQU].

11. See Joseph Diaz et al., Ex-Oklahoma City Cop Spending 263 Years in Prison for Rape and His Accusers Share Their Stories, ABC NEws (Apr. 21, 2016), https://abcnews.go.com/US/oklahomacity-cop-spending-263-years-prison-rape/story?id=38517467 [https://perma.cc/R2UR-GYH9].

12. See Schwab, supra note 10.

13. See id. 
Holtzclaw again made contact with the teenager and drove her to her mother's house. ${ }^{14}$ When the two arrived, Holtzclaw followed her to the porch. ${ }^{15}$ There, under the pretense of searching her, Holtzclaw "stuck his hands up under [her] shirt, under [her] bra and touched [her] breasts." 16 Afterwards, Holtzclaw turned the teenager around and raped her on her mother's porch. ${ }^{17}$

Both the Chambers and Holtzclaw allegations are examples of police sexual violence (PSV). While studies do not yet capture the full extent of PSV,${ }^{18}$ we do know that it is widespread, underreported, and under addressed. ${ }^{19}$ What makes the Chambers and Holtzclaw cases remarkable, in other words, is not that members of the public were sexually assaulted by the very officers sworn to protect them. What makes these examples unusual is that they were actually reported and that one of the officers was held accountable for his crimes. ${ }^{20}$

14. See id.

15. See id.

16. See id.

17. See id.

18. Most reports refer to PSV as "police sexual misconduct" ("PSM"). However, this Article will argue that police officers sexually assaulting arrestees in their custody is not mere misconduct, but rather an act of violence. For the purposes of consistency and for the sake of argument, any reference to PSV herein is synonymous with behavior traditionally recognized as PSM.

19. See Nancy Phillips et al., Extorting Sex with a Badge, PHILA. INQUIRER (Aug. 13, 2006), http://www.philly.com/philly/news/special_packages/inquirer/Extorting_sex_with_a_badge.html [https://perma.cc/K76H-ST9J] ("Hundreds of police officers across the country have turned from protectors to predators, using the power of their badge to extort sex, an Inquirer review shows .... Most police departments do little to identify the offenders, and even less to stop them."). Just recently, former Auburn, California police officer, Joseph James DeAngelo, was arrested in connection with a serious of killings, rapes, and assaults that transpired in the 1970s and 1980s. See Ray Sanchez et al., After Searching for More than 40 Years, Authorities Say an Ex-Cop is the Golden State Killer, CNN (Apr. 27, 2018), https://www.cnn.com/2018/04/25/us/golden-state-killer-development/index.html [https://perma.cc/8MVA-Q7BS]. DeAngelo was a police officer with the Auburn Police Department and the Exeter Police Department for six years, and authorities believe it is "[v]ery possibl[e]" that he committed some of the crimes during his time as a police officer. Id. Exeter Police Chief, John Hall, commented on the possibility that DeAngelo committed some of the crimes while acting as a police officer, stating, "It is absolutely shocking that someone can commit such heinous crimes, and finding out someone in a position of trust could betray that is absolutely unbelievable." Id. DeAngelo faces capital murder charges and is being held without bail in Sacramento. Id.

20. See Cara E. Trombadore, Police Officer Sexual Misconduct: An Urgent Call to Action in a Context Disproportionately Threatening Women of Color, 32 HARV. J. RACIAL \& ETHNIC JUST. 153, 155 (2016) (explaining that the Holtzclaw case "is unique in that it resulted in a criminal conviction and substantial penalty...."). Prosecutors withdrew the original charges against the officers in Anna Chambers's case and refiled charges of bribery and official misconduct. See Christina Carrega, Charges Dropped Against Ex-NYPD Officers Accused of Raping a Teen in Custody, ABC NEWs (Mar. 8, 2019), https://abcnews.go.com/US/charges-dropped-nypd-officers-accused-raping-teencustody/story?id=61540692 [https://perma.cc/H8HU-GA3Z]. Both officers were eventually sentenced to five years of probation. See Andrew Denney, Ex-NYPD Cops Get Five Years' Probation for Having Sex with Teen in Custody, NY POST (Oct. 10, 2019), https://nypost.com/2019/10/10/ex-nypd-cops-get5-years-probation-for-having-sex-with-teen-in-custody/ [https://perma.cc/5G6Y-KE3N]. 
The scale of PSV is staggering. A 2010 Cato Institute study found that PSV is the second-most reported form of police misconduct, after excessive force. ${ }^{21}$ Multiple studies indicate that women of color have been disproportionately affected by PSV for years. ${ }^{22}$ PSV victims ${ }^{23}$ often do not report their assaults to the police ${ }^{24}$ which suggests that the rate of PSV occurrence is even higher than existing reports indicate. ${ }^{25}$ PSV victims likely do not report their attacks for several reasons; including fear of retaliation, fear that no one will believe them, and fear that they will be blamed for the encounter. ${ }^{26}$ In the Holtzclaw case, for example, most of the victims did not report the assaults until Jannie Ligons-a fifty-seven-year-old woman who, unlike all the other victims, was not poorbecame the first woman to report her assault. ${ }^{27}$ It was only after the initial investigation began and investigators reached out to other potential victims, reassuring them that their allegations would be taken seriously, that others were willing to make allegations against Holtzclaw on the record. ${ }^{28}$ Because victims of PSV do not believe that the police will protect them-indeed, a police officer has just committed violence against them - they do not report assaults to the police. Additionally, as one of Holtzclaw's victims suggested, PSV victims likely do not know where to report or have any place in which they can report

21. Cato Inst., National Police Misconduct Statistics and Reporting Project, ANN. REP. (2010), (on file with author) ("Sexual misconduct was the second most common form of misconduct reported throughout 2010 with 618 officers involved in sexual misconduct complaints during that period, 354 of which were involved in complaints that involved forcible non-consensual sexual activity such as sexual assault or sexual battery.").

22. See Trombadore, supra note 20, at 168.

23. Both the terms "victim" and "survivor" are often used to refer to people who have experienced sexual violence, and individual preferences differ from person to person. Compare Jan van Dijk, Free the Victim: A Critique of the Western Conception of Victimhood, 16 INT'L REV. Victimology 1, 2-3 (2009) with Danielle Campoamor, I'm Not a Sexual Assault "Survivor"-I'm a Victim, HARPER's BAZAAR (May 21, https://www.harpersbazaar.com/culture/features/a20138398/stop-using-survivor-to-describe-sexualassault-victims/ [https://perma.cc/YTK4-G99A]. The word victim is often specifically used in the context of criminal law. See SEXUAL ASSAULT KIT INITIATIVE, VICTIM OR SURVIVOR: TERMINOLOGY FROM INVESTIGATION THROUGH PROSECUTION, https://sakitta.org/toolkit/docs/Victim-or-SurvivorTerminology-from-Investigation-Through-Prosecution.pdf [https://perma.cc/J5UZ-FSKE]. Another distinction is that victim refers to someone who has experienced sexual violence, where survivor may mean an individual who has moved through the process of recovery. See RAINN, KEY TERMS AND PHRASES, https://www.rainn.org/articles/key-terms-and-phrases [https://perma.cc/2ACF-GYAA]. For these reasons, we use "victim" throughout this article.

24. See Zoë Carpenter, The Police Violence We Aren't Talking About, NATION (Aug. 27, 2014), https://www.thenation.com/article/police-violence-we-arent-talking-about/ [https://perma.cc/XXG2M2L2] (interviewing an advocate of the Rape, Abuse, and Incest National Network who said, "Sexual assault is one of the most underreported crimes, and against police officers it's probably even less reported").

25. See Trombadore, supra note 20, at 167 (explaining that the structural barriers precluding further research and understanding about PSV suggests that "the data currently available represents a fraction of a larger picture").

26. See id. at $166,155$.

27. See Devon W. Carbado, Blue-on-Black Violence: A Provisional Model of Some of the Causes, 104 GEO. L.J. 1479, 1501 (2016).

28. See id; Trombadore, supra note 20, at 154. 
PSV. ${ }^{29}$ Consequently, PSV remains underreported and under-researched despite statistics revealing its high rate of occurrence..$^{30}$

The problem is compounded by a lack of regulation, which offers police officers a legal defense that might seem absurd: consent. Despite the numerous studies highlighting the dangers of PSV, several states do not prohibit sexual activity between police officers and people in custody. ${ }^{31}$ In February 2018, BuzzFeed published an article identifying thirty-five states that do not explicitly prohibit law enforcement officers from having sexual contact with people in their custody. ${ }^{32}$ Chambers's attorney, Michael David, similarly reported that at the time of the case, thirty-two states did not have laws expressly prohibiting the conduct. ${ }^{33}$ In such states, police officers accused of sexual assault can claim "consent" as a defense. ${ }^{34}$ Accordingly, despite the clear power imbalance between a police officer and a member of the public that the officer has stopped, questioned, held in custody, and perhaps even arrested, the officer can argue in response to a charge of sexual assault that their victim consented to the sexual activity. ${ }^{35}$

The epidemic of PSV, both in scale and in concept, is startlingly underanalyzed. Sexual assaults committed by police against members of the public operate at the intersection of two vital national conversations about police brutality and sexual violence and harassment. This Article is the first to fully address PSV as the product of both issues and to recommend systemic solutions sounding in both debates, including key insights from the study of masculinities.

The immediate problem PSV presents is that it is not made clearly illegal by state law and police department regulation. The deeper concern is that PSV is a symptom of broader cultural problems within police departments that can be helpfully parsed through the lens of masculinities theories. PSV arises from issues both with how police officers relate to the communities they patrol, especially men in those communities, and with how police officers and police culture treat women. The famous "blue wall of silence" ensuring loyalty even among police officers who commit misconduct magnifies these issues. Any

29. See Schwab, supra note 10.

30. See Trombadore, supra note 20, at 155-56 (citing Danielle McGurrin \& Victor E. Kappeler, Media Accounts of Police Sexual Violence: Rotten Apples or State-Supported Violence, in POLICING AND MISCONDUCT 121, 222 (Kim Michelle Lersch ed., 2002)).

31. See Samaha, supra note 1.

32. Id.

33. See James Ford, Woman Who Accused 2 NYPD Detectives of Raping Her Speaks Out, PIX 11 (Apr. 5, 2018), http://pix11.com/2018/04/05/anna-chambers-woman-who-accused-2-nypddetectives-of-raping-her-while-in-custody-faces-them-and-speaks-out/ [https://perma.cc/W7AZQ6P3].

34. See Samaha, supra note 1.

35. Not all sexual assault committed by police officers is perpetrated by male police officers, and not all victims of PSV are female. As will be discussed further in Part III infra, the most common and often most vulnerable victims of PSV are women, particularly women of color and transgender women. Still, so as not to leave any experiences out, this Article will use gender-neutral pronouns. 
attempt to meaningfully address PSV must take all of these factors into account to work both a legal and a cultural change. This Article offers such a solution.

The Article begins with a comprehensive accounting of the problem of PSV: assessing the limited statistics regarding the prevalence of PSV and canvassing existing state laws prohibiting PSV. ${ }^{36}$ Part I addresses the power dynamic between police officers and members of the public in custody, adopting a vocabulary of expressed versus subjective intent to explain why actual consent in such a context is impossible. Part II then examines the deeper causes of PSV through the frame of masculinities. It uses the concept of "hegemonic masculinity" to explain the multiple ways in which police officer-civilian interactions are affected by police officers' attempts to gain status with other men, particularly their fellow officers. Part III turns to a path forward, recommending substantive and procedural reforms to law and police department policy as well as proscriptive recommendations about how to shift police department culture.

I.

THE EPIDEMIC OF PSV

While PSV has gained national attention recently, PSV has been an underreported epidemic, disproportionately affecting women of color living in lower socioeconomic areas. Any analysis of PSV must begin by assessing how commonly it occurs, as well as whom it most commonly affects.

\section{A. Defining PSV}

PSV is an umbrella term that encompasses any coercion committed by a police officer with a sexualized component. ${ }^{37}$ This spans a wide range of acts, "from sexual harassment and extortion to forcible rape by officers." ${ }^{38}$ Although a uniform legal definition of PSV does not currently exist, New York's Policy and Advocacy Unit of the Civilian Complaint Review Board provides a helpful example, defining PSV as:

[V]erbal harassment of someone because of that person's sex, gender identity, or sexual orientation, as well as conduct involving the actual or

36. See infra Part II.B.

37. Scholars writing about PSV have used different terms, including police sexual misconduct as well as police sexual violence. Some commenters use the terms to distinguish between allegedly transactional exchanges of sexual activity and a police officer using discretion not to arrest or otherwise punish a member of the public and violent interactions in which the victim argued no consent took place. Because this Article argues that consent is impossible in sexual interactions between members of the public and police officers, it uses PSV in its broadest sense. For a helpful summary of this distinction, see Trombadore, supra note 20, at 171-72.

38. Andrea J. Ritchie, How Some Cops Use the Badge to Commit Sex Crimes, WASH. Post. (Jan. 12, 2018), https://www.washingtonpost.com/outlook/how-some-cops-use-the-badge-to-commitsex-crimes/2018/01/11/5606fb26-eff3-11e7-b390-

a36dc3fa2842_story.html?noredirect=on\&utm_term=.8d0bcabf4ae4 [https://perma.cc/52AJ-JPP5] 
threatened use of physical contact or force, including rape, assault, unwanted touching, and other forms of physical sexual contact ... with witnesses, victims, and defendants with whom members of service come into contact as a result of their job assignments. ${ }^{39}$

The U.S. Department of Justice similarly defines PSV as "sexual assault [by a law enforcement officer] without consent (rape), sexual contact procured by force, threat of force or coercion, and unwanted or gratuitous sexual contact such as touching or groping." 40 Most states, scholars, and scholarly reports, however, either do not define PSV at all or define the violence in very different ways. ${ }^{41}$ This lack of uniformity in defining PSV may be one reason why PSV has not been adequately addressed by state legislatures. ${ }^{42}$ Without a specific definition of PSV, legislatures may have difficulty conceptualizing the root of the problem, and thus, how to address it through the law. ${ }^{43}$

\section{B. Prevalence of PSV}

Because of the differing definitions of PSV, as well as other issues such as underreporting, it is functionally impossible to establish how many incidents of PSV occur per year. Even assuming under-inclusion and underreporting, however, numbers of reported incidents of sexual violence committed by police officers are disturbingly high. One six-year study conducted between 2009 and 2014 revealed that nearly one thousand police officers nationwide lost their licenses as a result of sexual violence allegations. ${ }^{44}$ Notably, the study surveyed only "state and local police, sheriff's officials, prison guards and school resource officers," 45 not federal officers. The study revealed that, of the nearly one thousand police officers who lost their license as a result of sexual violence, 549 police officers lost their licenses based on allegations of sexual assault or rape. ${ }^{46}$ Of those 549 police officers, 154 of them sexually assaulted prisoners. ${ }^{47}$ The study does not go into detail about how many police officers, if any, lost their license as a result of sexually assaulting a person in their custody. ${ }^{48}$

Buffalo News conducted a similar national study that revealed more than seven hundred credible cases of PSV in a span of ten years, ranging from 2005

39. Memorandum from N.Y.'s Policy \& Advocacy Unit of the Civil Complaint Review Bd. 1 (Feb. 14, 2018) (on file with author).

40. Law Enforcement Misconduct, U.S. DEP'T OF JUSTICE (July 28, 2017), https://www.justice.gov/crt/law-enforcement-misconduct\#sex [https://perma.cc/B8FB-5NCS]

41. Trombadore, supra note 20, at 163 .

42. See id. at 175.

43. See id. ("[U]nity in problem formulation has the potential to mobilize entire movements.").

44. See AP Investigation into Officer Sex Misconduct, by the Numbers, ASSOCIATED PRESS (Oct. 31, 2015), https://apnews.com/f61d495bb41d47968679c5b89a9907fc [https://perma.cc/8FREFFX8].
45. Id.
46. Id.
47. Id.
48. See id. 
to $2015 .{ }^{49}$ The study concluded that in more than 70 percent of the seven hundred cases, "officers wielded their authority over motorists, crime victims, informants, students and young people in job-shadowing programs." ${ }^{50}$ Of the police officers named in the data, only five offenders were women. ${ }^{51}$ Nearly all of the victims were women and adolescents. ${ }^{52}$ Former police officer Timothy Maher stated that these numbers are "just the tip of the iceberg." 53

Reported numbers fail to capture the actual number of PSV incidents for several reasons. One reason focuses on the status of the perpetrators: victims feel that other police officers will not view their allegations as reliable. Victims are understandably hesitant to report PSV when the entity to which the victim would typically file a claim is their abuser's place of employment. ${ }^{54}$ For obvious reasons, victims believe their abuser's employment and the loyalty of his coworkers will prevent their claims from being taken seriously. One of Holtzclaw's victims, for example, explained "I didn't think that [anyone] would believe me. I feel like all police will work together." ${ }^{55}$ When asked why she did not report the rape to the police, another of Holtzclaw's victims stated, "'What's the good of telling on the police? ... What kind of police do you call on the police?"'56 These testimonies are illustrative of the distrust victims feel when their abuser is a police officer, tainting the trust that they might otherwise feel that reporting the crime will lead to an investigation and arrest. ${ }^{57}$

There is even reason to believe that occasional media attention on horrifying examples of PSV, such as Holtzclaw's crimes, further discourages victims of PSV, and possibly victims of all crimes, to report them. Sociologists Matthew Desmond, Andrew Papachristos, and David Kirk analyzed how often members of the public called 911 to report crimes in Milwaukee in the wake of a highly publicized example of police brutality against a Black man. ${ }^{58}$ They concluded that "publicized cases of police violence against unarmed [B]lack men have a clear and significant impact on citizen crime reporting." 59 According to their study, individuals living in predominantly Black neighborhoods were less likely to call 911 to report crimes for a year following the media coverage,

49. See Matthew Spina, When a Protector Becomes a Predator, Buff. News (Nov. 22, 2015), https://s3.amazonaws.com/bncore/projects/abusing-the-law/index.html [https://perma.cc/B5H7D2M8].

50. Id.

51. See id.

52. Id.

53. Id.

54. See id. ("Victims may be even less likely to report [PSV] offenses when they fear it will be their word versus an officer's.").

55. See Trombadore, supra note 20, at 154.

56. Schwab, supra note 10.

57. See Trombadore, supra note 20, at 166.

58. Matthew Desmond et al., Police Violence and Citizen Crime Reporting in the Black Community, 81 AMER. SOC. REV. 857 (2016).

59. Id. at 870 . 
resulting in twenty thousand fewer calls to the police. ${ }^{60}$ It seems logical that victims of PSV would follow a similar pattern and be even less likely to report their assault in the wake of news, for example, that the officers accused of raping Anna Chambers received only probation.

Another central reason for underreporting is the identity of the victims most commonly assaulted by perpetrators of PSV. The victimology of PSV is deeply intersectional ${ }^{61}$ as police officers typically "target the most vulnerable - namely women of color, transgender and gender-nonconforming people, victims of domestic abuse, and people suspected of engaging in criminalized activity - to reduce the risk that their misconduct will be reported...." ${ }^{\prime 2}$ Police officers generally target these vulnerable groups because the groups are "often perceived as less credible, ${ }^{\prime 63}$ and thus are unlikely to succeed in reporting a police officer for PSV. ${ }^{64}$ A member of the Rape, Abuse \& Incest National Network advocacy group explained that police officers prey on these groups of people by making comments such as, "If you report me, then I'm going to report that you were breaking X, Y, or Z law." 65

Unsurprisingly, PSV disproportionately affects women of color. ${ }^{66} \mathrm{~A}$ number of cultural and historical reasons combine to make women of color, particularly Black women and girls, especially vulnerable to PSV. Sexual exploitation of Black women by White men in formal positions of power over them has been a shameful part of this nation's history since slavery. ${ }^{67}$ This exploitation is worsened by stereotypes and revisionist history that sexualizes Black women and girls, characterizing them as more likely to have consented to what was in fact a sexual assault. ${ }^{68}$ Given the communities that are more likely

60. See id.

61. See Kimberlé Crenshaw, Mapping the Margins: Intersectionality, Identity Politics, and Violence Against Women of Color, 43 STAN. L. REV. 1241, 1244 (1991).

62. Trombadore, supra note 20, at 158-59.

63. See INT'L ASS'N OF ChIEFS OF POLICE, AdDRESSING SeXual OfFEnSES AND MisCONDUCT BY LAW ENFORCEMENT: EXECUTIVE GUIDE 4 (2011), https://www.theiacp.org/sites/default/files/all/a/AddressingSexualOffensesandMisconductbyLawEnfor cementExecutiveGuide.pdf [https://perma.cc/57ZW-468J].

64. See Steven Yoder, Officers Who Rape: The Police Brutality Chiefs Ignore, AL JAZEERA (Jan. 19, 2016), http://america.aljazeera.com/articles/2016/1/19/sexual-violence-the-brutality-thatpolice-chiefs-ignore.html [https://perma.cc/4F32-G8EH].

65. Id.

66. Id.; see also Tasha Fierce, Black Women are Beaten, Sexually Assaulted and Killed by Police. Why Don't We Talk About It?, ALTERNET (Feb. 26, 2015), https://www.alternet.org/activism/black-women-are-beaten-sexually-assaulted-and-killed-police-whydont-we-talk-about-it [https://perma.cc/UTP2-HHKM] ("Black women are disproportionately targeted by police and face the threat of not only being shot, but of being sexually assaulted.").

67. See Trombadore, supra note 20, at 168. ("Sexual exploitation of [B]lack women in the United States can be traced to slavery, for it is well-established that [B]lack women 'endured rape, forced breeding and physical assaults as a means for profit and brute intimidation.").

68. Id. 
to have repeated interactions with law enforcement ${ }^{69}$ and the ongoing role of purported consent in PSV, it is unsurprising that Black women have been disproportionately victimized by PSV.

Black women, of course, are not the only women of color that are disproportionately affected by PSV. Latinx women, American Indian and Alaska Native women, and LGBTQ+ women also face a higher risk of sexual assault than heterosexual White women. ${ }^{70}$ All of these groups of women have historically been sexually exploited and otherwise marginalized, making victimization and oppression more common and less likely to be punished. ${ }^{71}$ While women generally are disproportionately impacted by rape and sexual assault,$^{72}$ women of color run an even higher risk of rape or sexual assault as a result of their race and their gender. ${ }^{73}$ Although approximately 60 percent of the population identifies as White, ${ }^{74}$ only 18 percent of rape victims are White. The rate of victimization of nonwhite people is strikingly disproportionate to their numbers in the overall population. ${ }^{75}$

The particular vulnerability of women of color, however, is not meant to exclude men, specifically men of color, who have also been targets of PSV. One of the most notorious examples of PSV occurred in August 1997, when a Haitian man named Abner Louima was arrested and taken back to the police station, where two New York Police Department officers brutally sodomized him with a broomstick. ${ }^{76}$ Louima suffered from a ruptured bladder and colon, causing him to spend two months in the hospital. ${ }^{77}$ The two officers were only sentenced to a

69. See Carbado, supra note 27, at 1490 ("“P]olice officers can almost always find a justification to investigate an African-American for some crime.").

70. See id; Trombadore, supra note 20, at 169.

71. See Trombadore, supra note 20, at 168-69.

72. See Victims of Sexual Violence: Statistics, RAINN, https://www.rainn.org/statistics/victimssexual-violence [https://perma.cc/JF5R-7QPJ] (explaining that 90 percent of adult rape victims are female while one in every ten rape victims are male).

73. See Prevalence Rates, END RAPE ON CAMPUS, https://endrapeoncampus.org/new-page-3 [https://perma.cc/B5C5-D7W9].

74. Quick Facts, U.S. CENSUS BUREAU, https://www.census.gov/quickfacts/fact/table/US/PST045217\#qf-headnote-b [https://perma.cc/CTW7SXZN].

75. See CTRS. For DiseASE CONTROL \& PREVENTION, 2010 SUMMARY REPORT, NATIONAL INTIMATE PARTNER AND SEXUAL VIOLENCE SURVEY 83 (2011), https://www.cdc.gov/ViolencePrevention/pdf/NISVS_Report2010-a.pdf [https://perma.cc/Y5GM2CG9].

76. See K.C. Baker et al., Two Cops Charged for Torturing Abner Louima With a Broomstick in 1997, N.Y. DAILY NEWS (Aug. 8, 2017), http://beta.nydailynews.com/new-york/nyc-crime/2-copseyed-sex-assault-70th-pct-suspect-brutalized-article-1.785482 [https://perma.cc/8QP6-YP5K]. Unlike Chambers's and Holtzclaw's attacks, Louima's assault was appropriately labeled "police brutality." Another reason this Article uses PSV rather than PSM is to emphasize that women, specifically those of color, being sexually assaulted at the hands of police officers should be labeled "police brutality" rather than mere misconduct.

77. See Sewell Chan, The Abner Louima Case, 10 Years Later, N.Y. Times: CiTY RoOM (Aug. 9, 2007), https://cityroom.blogs.nytimes.com/2007/08/09/the-abner-louima-case-10-years-later/ [https://perma.cc/BF36-HVTZ]. 
few years of probation. ${ }^{78}$ Louima's assault has become one of the most famous examples of sexual assault of a male victim, and an exception to widespread dismissal or even laughing reactions to male victims of sexual assault. ${ }^{79}$

Even police officers recognize that PSV is a widespread and significant problem. ${ }^{80}$ Norm Stamper, a former Seattle police chief, published a book in which he stated, "You won't find a major law enforcement agency that has been around for more than five minutes that has not had a chapter in its history of sexual abuse by a police officer on duty. We've got too many rapists in uniform." ${ }^{81}$ Penny Harrington, former police chief of Portland, Oregon, and founder of the National Center for Women and Policing, also implicitly acknowledged the problem when she said, "The women are terrified .... Who are they going to call? It's the police who are abusing them." 82 Finally, Sarasota Police Chief Bernadette DiPino remarked, "It's happening in probably every law enforcement agency across the country." 83

Despite current and former police officers in high positions of power acknowledging this problem, state legislatures have failed to adequately address the issue. And in spite of the underreporting of PSV discussed briefly above, PSV is still the second-most reported form of police violence, after excessive force ${ }^{84}$ Until legislatures recognize the importance and immediate harm this issue poses to people subjected to the criminal justice system, "women will continue to pay a heavy price." 85 The next Section turns to what statutes currently exist that address PSV and why they are inadequate.

\section{Current Laws Prohibiting PSV and an Introduction to the Power Dynamic}

In all fifty states, it remains a crime for anyone, including law enforcement officers, to commit sexual assault. ${ }^{86}$ However, approximately thirty states do not have statutes expressly prohibiting sexual conduct between a law enforcement officer and a person in custody. ${ }^{87}$ Albert Samaha's BuzzFeed article discussing

78. See Alan Feuer, 2 Ex-Officers in Louima Case Get Probation for Lying, N.Y. TIMES (Feb. 10, 2001), https://www.nytimes.com/2001/02/10/nyregion/2-ex-officers-in-louima-case-get-probationfor-lying.html [https://perma.cc/3GBA-AC7X]. Remarkably, Louima won $\$ 8.7$ million in settlements following the attack. See Chan, supra note 77.

79. See Bennett Capers, Real Rape Too, 99 CALIF. L. REv. 1259, 1261-64 (2011).

80. See Trombadore, supra note 20, at 160-61.

81. Id. at 161 .

82. See Phillips et al., supra note 19 (internal quotation marks omitted).

83. See Trombadore, supra note 20, at 161 (internal quotation marks omitted).

84. See CATO InST., supra note 21 and accompanying text.

85. Katharine Bodde \& Erika Lorshbough, There's No Such Thing as 'Consensual Sex' When a Person is in Police Custody, N.Y.C.L. UNION (Feb. 23, 2018), https://www.nyclu.org/en/news/theresno-such-thing-consensual-sex-when-person-police-custody [https://perma.cc/2A9C-S3NQ].

86. See Andrea Ritchie, Survivors of Sexual Violence by Police Need More Than a Quick Fix, REWIRE NEwS (Apr. 3, 2016), https://rewire.news/article/2018/04/03/survivors-sexual-violence-policeneed-quick-fix/ [https://perma.cc/4AUF-K46U] [hereinafter Ritchie, Quick Fix].

87. See Samaha, supra note 1. 
Anna Chambers's case included a graphic identifying which states specifically prohibited police officers from having sexual contact with a member of the public held in custody, showing only fifteen states with such a specific prohibition. ${ }^{88}$ Since that article was published, several states have passed or considered statutes attempting to address PSV, but a majority still lack any direct prohibition. ${ }^{89}$

Existing statutes address the illegality of sexual contact between law enforcement and members of the public in a variety of ways. ${ }^{90}$ Some states explicitly say "law enforcement" or "peace officer" in definitions of prohibited conduct, making clear that any sexual contact between a member of the police and a member of the public is a crime. Arizona's statute is one of the most straightforward, stating that "[a] peace officer commits unlawful sexual conduct by knowingly engaging in sexual contact, oral sexual contact or sexual intercourse with any person who is in the officer's custody or a person who the officer knows or has reason to know is the subject of an investigation." 91

A number of statutes both name police officers and focus on persons in custody. Alaska, for example, specifies that if "while employed in the state by a law enforcement agency as a peace officer" the officer "engages in sexual penetration with a person with reckless disregard that the person is in the custody or the apparent custody of the offender, or is committed to the custody of a law enforcement agency," that officer has committed sexual assault in the third degree. ${ }^{92}$ Hawaii similarly prohibits a law enforcement officer from "knowingly subject[ing] to sexual penetration ... a person in custody." ${ }^{.3}$ California forbids "peace officer[s]" from engaging in sexual activity with anyone "confined in a detention facility," which includes interview and interrogation rooms as well as vehicles used to transport people after their arrest. ${ }^{94}$

Other states use a broader description of the circumstances in which sexual activity is not permitted than when a person is in custody. For example, Kansas lists "traffic stop, a custodial interrogation, an interview in connection with an investigation, or while the law enforcement officer has such person detained" as circumstances in which sexual contact between an officer and member of the

88. Id.

89. See Colo. Rev. STAT. § 18-3-405.7 (2019); KAN. STAT. ANN. § 21-5512 (2019); LA. STAT. ANN. § 14:41.1 (2020); MD. CODE ANN., CRIM. LAW § 3-314 (West 2002); N.Y. PENAL LAW § 130.05 (2019); VT. STAT. ANN. tit. 13, § 3259 (West 2018).

90. The graphic labels Indiana as a state with a specific prohibition of sexual contact between police officers and members of the public, but the authors were unable to locate a statute establishing that offense. See Samaha, supra note 1.

91. ARIZ. REV. STAT. ANN. § 13-1412(A) (2020).

92. ALASKA STAT. ANN. $§ 11.41 .425(\mathrm{a})(4)$ (West 2019). If the officer engages in sexual contact, rather than sexual penetration, the offense is sexual assault only in the fourth degree. ALASKA STAT. ANN. § 11.41.427(a)(3) (West 2019).

93. HAW. REV. STAT. ANN. § 707-731(1)(c)(v) (West 2020).

94. CAL. PENAL CODE $§ 289.6(a)(2)$ (West 2020). 
public is illegal. ${ }^{95}$ Florida specifies that any "law enforcement officer, correctional officer, or correctional probation officer" is guilty of a felony if they commit actions that fit under the general definition of sexual battery while they are "acting in such a manner as to lead the victim to reasonably believe that the offender is in a position of control or authority as an agent or employee of government." 96 Along similar lines, Colorado prohibits any peace officer from having sexual activity with someone contacted "for the purpose of law enforcement or ... the exercise of the officer's employment activities," someone who is or the officer causes to believe is the subject of an active investigation, or someone to whom the officer makes "any show of real or apparent authority." 97

All of the above statutes specifically identify members of law enforcement and prohibit a relatively broad range of sexual acts, although they display some variety in whether the victim is in custody, the subject of an active investigation, or simply subject to the police officer's authority. By contrast, other states focus more on the custodial aspect, rather than necessarily identifying law enforcement officers specifically. ${ }^{98}$ North Carolina statutes simply prohibit:

[A] person having custody of a victim of any age or a person who is an agent or employee of any person, or institution, whether such institution is private, charitable, or governmental, having custody of a victim of any age engag[ing] in vaginal intercourse or a sexual act with such victim .... ${ }^{99}$

Oregon defines a crime called "custodial sexual misconduct," which occurs where a state employee has sexual intercourse with a person "in the custody of a law enforcement agency following arrest." 100 Washington is more specific, establishing the same offense where "the perpetrator is a law enforcement officer" and the victim is "detained, under arrest, or in the custody of a law enforcement officer," and further notes that "[c]onsent of the victim is not a defense to prosecution." 101 Utah defines "custodial sexual relations" where the victim is "a person in custody," and similarly specifies that consent is not a defense. ${ }^{102}$

Still more states tweak the custodial description slightly by emphasizing control or other supervisory authority exercised by the perpetrator over their victim, the approach suggested in the Model Penal Code. ${ }^{103}$ For example, Ohio

95. KAN. STAT. ANN. § 21-5512 (2019)

96. Fla. STAT. ANN. § 794.011(4)(e)(7) (West 2019).

97. COLO. REV. STAT. §§ 18-3-405.7(a), (c) (2019).

98. In addition to those quoted, see also LA. STAT. ANN. § 14:41.1 (2020); MD. CODE ANN., CRIM. LAW § 3-314 (West 2002); N.Y. PENAL LAW § 130.05 (2019); VT. STAT. ANN. tit. 13, § 3259 (West 2018).

99. N.C. GEN. STAT. ANN. § 14-27.31(b) (West 2019).

100. OR. REV. STAT. ANN. $\S \S 163.452(1),(1)(a)(A)$ (West 2020).

101. WASH. REV. CODE ANN. § 9A.44.160(1)(a)(i)-(ii), (1)(b)(2) (West 2019).

102. UTAH CODE ANN. § 76-5-412(2)(a)(ii)(A), (7)(b) (West 2020).

103. See Model Penal Code $\S \S 213.3-4$ (AM. LaW InST., Proposed Sections 213.0 to 213.11 2015). 
bans sexual conduct where one person is "in custody of law ... and the offender has supervisory or disciplinary authority over the other person." 104 North Dakota prohibits sexual contact between a person "in official custody or detained in a hospital, prison, or other institution" and an actor who has "supervisory or disciplinary authority over that other person." 105 New Jersey includes in its definition of sexual assault circumstances where "[t]he victim is on probation or parole, or detained in a hospital, prison or other institution and the actor has supervisory or disciplinary power over the victim by virtue of the actor's legal, professional or occupational status." ${ }^{106}$ Connecticut establishes that if someone "is detained in a hospital or other institution and the actor has supervisory or disciplinary authority over such other person," the actor is guilty of sexual assault. ${ }^{107}$ Georgia states that someone "who has supervisory or disciplinary authority over another individual commits sexual assault" when the perpetrator "[i]s an employee or agent of a law enforcement agency and engages in sexual contact with such other individual who the actor knew or should have known is contemporaneously... being detained by or is in the custody of any law enforcement agency." 108 Oklahoma focuses on the victim, specifying that rape has occurred " $[\mathrm{w}]$ here the victim is under the legal custody or supervision of a state agency, a federal agency, a county, a municipality or a political subdivision and engages in sexual intercourse with a state, federal, county, municipal or political subdivision employee or an employee of a contractor of the state, the federal government, a county, a municipality or a political subdivision that exercises authority over the victim." 109 Notably, some states prohibit sexual contact between a person with supervisory or disciplinary authority and a person under that authority, but only where the person in authority uses that authority to coerce the victim to submit. ${ }^{110}$

These states are the only ones that criminalize sexual activity between a police officer and a member of the public. In the majority of states, only general sexual assault statutes apply. Therefore, if a person in custody alleges that a police officer sexually assaulted them, the police officer can raise consent as a defense and argue that the sexual contact was consensual sexual activity rather than sexual assault. This is particularly pernicious due to the assumption, in

104. OHio REv. CoDE ANN. § 2907.03(A)(6) (West 2020).

105. N.D. CENT. CODE ANN. § 12.1-20-07(1)(d) (West 2020)

106. N.J. STAT. ANN. § 2C:14-2(c)(2) (West 2020).

107. CONN. GEN. STAT. ANN. § 53a-71(a) (West 2019).

108. GA. CODE ANN. § 16-6-5.1(b), (b)(3) (West 2003).

109. OKLA. STAT. ANN. tit. 21, § 1111(A)(7) (West 2019).

110. See, e.g., N.H. REV. STAT. ANN. § 632-A:2(I)(n) (West 2018) ("When the actor is in a position of authority over the victim and uses this authority to coerce the victim to submit ...."); TENN. CODE ANN. § 39-13-527(a)(3)(A) (West 1955) ("The defendant was at the time of the offense in a position of trust, or had supervisory or disciplinary power over the victim by virtue of the defendant's legal, professional or occupational status and used the position of trust or power to accomplish the sexual contact."); WYO. STAT. ANN. § 6-2-303(a)(vi) (West 2019) ("The actor is in a position of authority over the victim and uses this position of authority to cause the victim to submit."). 
"much of the policing literature" that "police are a desired sexual commodity who are routinely tempted by women willing to trade 'sexual favors' for leniency." 111

This defense is problematic because it ignores the power dynamic between a police officer and a civilian in custody - a power dynamic that many have argued "makes consent impossible." 112 New York Assemblyman Edward Braunstein, who sponsored the successful New York bill, argued that "[t]he power dynamic between an individual in custody and a law enforcement officer is such that the person in custody is powerless to consent to sexual activity." 113 The New York Civil Liberties Union counselors concluded the same, reasoning that "[a]nyone in police custody implicitly understands ... that not going along with a police officer's wishes could have serious adverse consequences."114 The next Section addresses the power dynamic between police officer and civilian in more specificity.

\section{The Power Dynamic: Law Enforcement Officers and "Consenting" Civilians in Custody}

While a definition of consent does not exist, ${ }^{115}$ there is a general understanding that consent indicates a person's willingness to engage in a particular sexual act. ${ }^{116}$ There are two dimensions to this consent. First, there is expressed consent: a verbal or physical manifestation of consent. ${ }^{117}$ Second, there is subjective consent: the internal, subjective choice to engage in sexual activity. Ideally, both expressed consent and subjective consent are present. In some circumstances, however, this is not the case. For example, a person might give expressed consent while not wanting to engage in sexual activity because fear, threats, or coercion made them feel as if they had no choice. Conversely, a person engaged in sadomasochistic practices might subjectively want sexual

111. Peter B. Kraska \& Victor E. Kappeler, To Serve and Pursue: Exploring Police Sexual Violence Against Women, 12 JUST. Q. 85, 88 (1995).

112. Bodde et al., supra note 85 .

113. Assembly Passes Legislation to Prohibit Sexual Contact Between Police Officers and Individuals in Custody, N.Y. ASSEMBLY, ASSEMBLYMANEDWARDC. BRAUNSTEIN ASSEMBLY DISTR. 26 (Feb. 7, 2018), http://nyassembly.gov/mem/?ad=026\&sh=story\&story=79457 [https://perma.cc/4432-DUG9].

114. Bodde et al., supra note 85 .

115. See Legal Role of Consent, RAINN, https://www.rainn.org/articles/legal-role-consent [https://perma.cc/7K8E-HRQS] (“There is no single legal definition of consent.").

116. See Michal Buchhandler-Raphael, Sexual Abuse of Power, 21 U. FLA. J.L. \& PUB. POL'Y 77, 117 (2010).

117. For conceptual purposes, expressed consent could arguably include permission that is implied through the absence of protest, as opposed to affirmative consent. 
contact but—because of their preferences for masochistic role-playing — express non-consent. ${ }^{118}$

PSV implicates both mismatches in ways that demonstrate the need for a bright-line rule prohibiting sexual contact between an on duty police officer and a member of the public. First, the nature of the relationship between a police officer and a member of the public demonstrates why the risk of expressed but not subjective consent is so high. When a police officer has a person in their custody, the power the police officer holds over that civilian effectively makes subjective intent irrelevant.

To determine whether a sexual act between a person in a position of power and a person not similarly situated was consensual, the key question is whether the victim participated in the sexual demands as a result of coercion. In the context of a police officer and a person in custody, we argue that the potential for coercion is so great that there can never be meaningful consent. ${ }^{119}$

Imagine an allegation of sexual assault against a police officer in which the officer argues the sexual encounter was consensual. Assume that the factfinder is convinced that the member of the public expressed consent. Even then, the police officer's control over the civilian renders subjective intent absent. As Michal Buchhandler-Raphael has argued, the power imbalance means that any purported consent is the product of a "one-sided abuse of power rather than through mutual agreement." 120 Therefore, the outward appearance of permission cannot be viewed as actual consent because it is "affected heavily by fears, pressures, and constraints" resulting from the abuser's power. ${ }^{121}$

This further implicates a distinction between nonconsensual and unwanted sex. For example, Robin West defined a difference between the two:

Sometimes unwanted sex is non-consensual, and when it is, it is rape. Sometimes, however, unwanted (or unwelcome or undesired) sex is "consensual," in all the ways that matter to law, and when such, it is not rape, and... not the target of criminal rape law. However, even consensual sex that is unwanted-meaning, unwanted sex that is not rape - might nevertheless be harmful, injurious, and the product of not-

118. See Michelle J. Anderson, From Chastity Requirement to Sexuality License: Sexual Consent and A New Rape Shield Law, 70 GEO. WASH. L. REV. 51, 131 (2002) (describing a sexual assault case involving claims of voluntary sadomasochistic activity). People who engage in sadomasochism describe negotiating consent, however, as "a crucial aspect of their sexual play" and reject descriptions of sadomasochism as nonconsensual. See id. at 135-36.

119. See Buchhandler-Raphael, supra note 116, at 119.

120. See Buchhandler-Raphael, supra note 116, at 117; see also Mark Treyger, There is No Sexual Consent While Under Police Custody, Medium (Oct. 24, 2017), https://medium.com/@councildistrict47/there-is-no-sexual-consent-while-under-police-custody7f58b9fdf33d [https://perma.cc/VPH5-2BCC] ("[T] he power dynamics between a trusted agent of our criminal justice system and an individual under supervision mean that no sexual consent can be given entirely free from coercion.").

121. See Buchhandler-Raphael, supra note 116, at 117. 
so-subtle background conditions of necessity and coercion .... ${ }^{122}$

West thus concluded that there are undeniably instances in which a person is incapable of consenting to sexual activity. The law, however, does not currently capture these situations-where there is a lack of subjective consent-if expressed consent is arguably or theoretically present. ${ }^{123}$

PSV is a prime example of such unwanted sex. Undoubtedly, many incidents of PSV are lacking both expressed and subjective consent. But given the power differential between a police officer and a member of the public, the risk of unwanted sex with expressed but not subjective consent is unacceptably high. Even further, we argue that in the context of PSV, subjectively wanted sex should be considered nonconsensual. In other words, even if it could be proven that a person in custody actually expressed consent and acknowledged their subjective consent, any sexual contact between that person and a police officer holding them in custody should be considered PSV and illegal.

One justification for a bright-line rule is to avoid difficult evidentiary determinations. Such determinations may rely upon biased judgments of the credibility of sexual assault victims, particularly women. ${ }^{124}$ The power imbalance inherent in the relationship between law enforcement officers and civilians makes any type of consent suspect at best and functionally meaningless at worst.

A second justification for a bright-line rule is a stronger statement of principle: the context of a police officer holding a civilian in custody vitiates consent. This may seem like an overly rigid rule, but similar bright-line rules regarding consent apply in other comparable contexts.

The most familiar rule of strict liability regarding consent is probably statutory rape. The crime of statutory rape is based on a simple concept: people below a certain age are legally incapable of consenting to sexual activity. ${ }^{125} \mathrm{In}$ the majority of states, therefore, a person who has sexual intercourse with a minor is guilty of statutory rape, even if the adult honestly believed that the minor was over the age of consent. ${ }^{126}$ Although the simplicity of the rule is a useful comparison, the justification for the rule is different in an important way: a minor is considered less competent to make decisions regarding sexual activity than an

122. Robin L. West, Desperately Seeking a Moralist, 29 HARV. J.L. \& GENDER 1, 19 (2006) (emphasis in original).

123. See id.

124. See generally Anderson, supra note 118 (discussing the historical and continuing use of rape victims' sexual history to impeach their credibility). One of us has previously written about another context in which women's statements about their own bodies are not believed; descriptions of pain as part of disability claims. See Dara E. Purvis, A Female Disease: The Unintentional Gendering of Fibromyalgia Social Security Claims, 21 TEX. J. WOMEN \& L. 85, 109-14 (2011).

125. See Erin K. Jackson, Addressing the Inconsistency Between Statutory Rape Laws and Underage Marriage: Abolishing Early Marriage and Removing the Spousal Exemption to Statutory Rape, 85 UMKC L. REV. 343, 361-64 (2017).

126. See Russell L. Christopher \& Kathryn H. Christopher, The Paradox of Statutory Rape, 87 IND. L.J. 505, 517 (2012). 
adult. No such principle is applicable to people in the custody of law enforcement, and the comparison raises potentially problematic assumptions about female agency and sexual decision-making that historically undergirded gendered statutory rape laws. ${ }^{127}$

A much closer analogy provides a clearer parallel: people held in prison. Even jurisdictions that do not explicitly reject the concept of "consensual" sex with a person in law enforcement custody generally recognize the imbalanced power dynamic inherent in the custodial relationship between prisoners and prison guards. ${ }^{128}$ These jurisdictions have implemented laws to protect vulnerable persons from exploitation by corrections officers. ${ }^{129}$ Moreover, "[s]ome United States district courts have concluded that the inherent power differential between guards and inmates makes sexual relationships between them coercive," thereby deeming any sexual activity between them to be nonconsensual. ${ }^{130}$

At the federal level, for example, the U.S. Congress implemented the Prison Rape Elimination Act of 2003 (PREA), which "established a 'zero-tolerance standard' for rape in prisons in the United States." ${ }^{131}$ Implementation of the PREA underscores that "in a custodial context, consent is a legal impossibility." 132 The federal government and a majority of states have since followed suit by criminalizing sexual activity between prison workers and those in their custody. ${ }^{133}$ The statutory language of such bans is explicit and clear. For example, multiple states say outright that purported consent of an inmate is not a defense to alleged violations of the statute. ${ }^{134}$ Proposed revisions to the Model Penal Code similarly criminalize sexual contact between someone who "holds any position of authority or supervision" over a victim "detained in a . . .

127. See Frances Olsen, Statutory Rape: A Feminist Critique of Rights Analysis, 63 TEX. L. REV. 387, 404-06 (1984).

128. See, e.g., COLO. REV. STAT. ANN. § 18-7-701 (2019).

129. See id. (detailing that an inmate is incapable of consenting to sexual acts with a correction officer).

130. Merideth J. Hogan, If Orange is the New Black, is Coercion the New Consent? An Analysis of the Tenth Circuits Decision to Allow Guards to Use an Inmate's Alleged Consent as a Defense in a Sexual Abuse Allegation [Graham v. Sheriff of Logan County, 741 F.3d 1118 (10th Cir. 2013)], 54 WASHBURN L.J. 425, 425-26 (2015).

131. Implementing the Prison Rape Elimination Act, Presidential Memorandum, 77 Fed. Reg. 20873 (May 17, 2012), appended to 34 U.S.C. $\$ 30301$ (2018).

132. Deborah M. Golden, It's Not in My Head: The Harm of Rape and the Prison Litigation Reform Act, 11 CARDOZO WOMEN's L.J. 37, 39 (2004).

133. See id. at 40 n. 16 (listing statutes).

134. See, e.g., D.C. CODE ANN. § 22-3017(a) (West 2001) (stating specifically that " [c]onsent is not a defense to a prosecution under $\S \S 22-3013$ to 22-3016”); FLA. STAT. ANN. $§ 944.35$ (3)(b)(3) (West 2019) (prohibiting sexual activity, defined therein, between inmates and prison guards, and specifically stating that "[t]he consent of the inmate or offender supervised by the department in the community to any act of sexual misconduct may not be raised as a defense to a prosecution under this paragraph"); NEB. REV. STAT. § 28-332.01 (2006) (explaining that consent is not a defense to "sexual penetration or sexual conduct"). 
custodial institution" or has a "status involving state-imposed restrictions on liberty." 135

Despite formally recognizing the power imbalance between inmates and prison guards, only a handful of states explicitly prohibit sexual activity between law enforcement officers and those in their custody. ${ }^{136}$ Even fewer states explicitly codify that consent is not a defense to such sexual activity. ${ }^{137}$ Yet a police officer's relationship with a person in custody is comparable to the relationship between a prison guard and a prisoner. Most importantly, and most obviously, police officers have a custodial relationship with an arrestee similar to that between a prison guard and a prisoner. A police officer has the ability to deprive someone of their liberty if they are accused (or threatened with a charge) of breaking a law. ${ }^{138}$ Because of the power dynamic resulting from the relationship between police officers and those in their custody, as well as prison guards and prisoners, consent to sexual activity under the pressure of the criminal justice system is not possible. ${ }^{139}$

One response to this conclusion is to argue that a bright-line rule stating that a member of the public cannot consent to sexual activity with a police officer takes away the agency and autonomy of a member of the public who actually wants to engage in the sexual activity. ${ }^{140}$ This is true to the extent that their consent would be rendered effectively meaningless for certain types of interactions. If a member of the public wishes to engage in sexual activity with a police officer, however, they would be free to do so when that officer is off duty. Given the substantial risk of unwanted sexual activity as described above, it is a comparably small restriction on the rights of both police officers and their willing sexual partners to require that any sexual interactions take place in a context that guarantees meaningful consent.

\section{Police Departments' Policies (or Lack Thereof) Addressing PSV}

Even where state law does not criminalize sexual activity between police officers and those in custody, internal police procedures could provide an alternative form of regulation, offering potentially milder sanctions while still expressing an internal norm against such behavior. Unfortunately, as with

135. Model Penal Code: SeXual AsSault AND Related OfFenses $\S \S 213.4(1)(\mathrm{b})(\mathrm{i})-(\mathrm{ii})$ (Tentative Draft No. 2, 2016).

136. See supra note 110 and accompanying text.

137. See supra note 110 and accompanying text.

138. See, e.g.., State v. Felton, 339 So. 2d 797, 799, 801 (La. 1976) (holding a police officer accountable for extortion when he forced a woman to have sexual intercourse with him by threatening to arrest her).

139. See Buchhandler-Raphael, supra note 116, at 82 ("[C]onsent to sex is not obtained when it is induced by fears and pressures stemming from sexual abuse of power.").

140. For a similar argument in a different context, see Leigh Goodmark's criticism of domestic violence mandatory arrest policies as prioritizing "safety and accountability over autonomy." Leigh Goodmark, Autonomy Feminism: An Anti-Essentialist Critique of Mandatory Interventions in Domestic Violence Cases, 37 FLA. ST. U. L. REV. 1, 4 (2009). 
statutes prohibiting such behavior, most police departments do not have official policies regarding sexual activity with civilians.

While there is no recent data detailing precisely how many police departments across the United States have such policies, several reports in recent years detailed a lack of police department policies addressing PSV. ${ }^{141}$ In 2017, for example, Andrea J. Ritchie and Delores Jones-Brown examined the policies of thirty-six police departments across the country, including a majority of the nation's top thirty law enforcement agencies. ${ }^{142}$ Their research revealed that "[a]lthough departments generally had a policy explicitly prohibiting sexual harassment and misconduct among employees, more than half had no policy explicitly prohibiting [PSM] against members of the public."143

Ritchie and Brown's research also compared several police department policies regarding PSV. Some policies were extremely detailed, but most were vague or not sufficiently descriptive. ${ }^{144}$ For example, Montgomery County, Maryland's police department policy prohibited PSV under the larger umbrella of sexual harassment, stating that "[c]ounty employees must not subject other employees, contractors, consultants, citizens, applicants, customers, or clients to sexual harassment. An employee found to have engaged in sexual harassment will be subject to appropriate disciplinary action, which may include dismissal." 145 The policy then defined sexual harassment as:

$[R]$ equests for sexual favors; the use of threats or force to obtain sexual favors; sexual propositions or innuendo; suggestive comments; sexually oriented teasing or joking; jokes about gender-specific traits; unwelcome or uninvited touching, patting, pinching, or brushing against another's body; obscene spoken or written language; obscene gestures, and display of offensive or obscene printed or visual material. ${ }^{146}$

This policy encompasses a wide range of PSV. It does not, however, acknowledge PSV as a specific form of harm or discuss the imbalanced power relationship between police officer and civilian that would negate expressed consent.

Nonetheless, the level of detail of prohibited conduct in Montgomery County's policy is arguably better than even shorter examples such as Washington, D.C.'s Metropolitan Police Department, which states only that "[o]fficers shall ... [n]ot conduct themselves in an immoral, indecent, lewd, or

141. See e.g., Timothy M. Maher, Police Sexual Misconduct: Officers' Perceptions of Its Extent and Causality, 28 CRIM. JUST. REV. 355, 377 (2003) ("No agency represented in this sample had a formal written policy on PSM.").

142. See Andrea J. Ritchie \& Delores Jones-Brown, Policing Race, Gender, and Sex: A Review of Law Enforcement Policies, 27 WOMEN \& CRIM. JUST. 21, 22 (2017). The nation's top thirty law enforcement agencies were determined by looking at the number of officers on the force. $I d$.

143. Id. at 29 (emphasis added).

144. See id. at 34-36.

145. Id. at 34 .

146. Id. 
disorderly manner or in [sic] manner which might be construed by an observer as immoral, indecent, lewd, or disorderly." 147 If police department policies are meant to express an internal norm condemning PSV, such broad edicts are less helpful. Indeed, at least some police officers who engage in sexual contact with members of the public likely do not believe they are committing an immoral or lewd act.

Montgomery County Police Department and Washington, D.C.'s Metropolitan Police Department have one thing in common: both police departments actually have a policy discussing PSV. Their existing PSV policies put them in the minority. ${ }^{148}$ As Ritchie and Brown's research revealed, most police departments in the United States do not have PSV policies at all. ${ }^{149}$ Consequently, two major problems arise: (1) there is silence around PSV, which marginalizes victims of PSV or makes them feel alone in their experience, and (2) offending police officers are subsequently kept on the job, a process known as the "officer shuffle," which puts more people in danger. ${ }^{150}$

First, the lack of police department policies defining PSV has led to a lack of uniformity in what the behavior truly constitutes. ${ }^{151}$ Prior studies suggest that when a victim of a crime does not know how that crime is characterized, they are more likely to feel alone and as if they are the only victim. ${ }^{152}$ Equally troubling is the contrast in treatment of different types of police misconduct: "excessive use of force" is defined and regulated by nearly all police departments, yet PSV is not. ${ }^{153}$ Treating PSV differently than other misconduct

147. Id. at 35 .

148. See id. at 33

149. See id. ("The majority of departments have no policies or training in place explicitly addressing [PSV].”).

150. See Andrea Ritchie, InVisible No More: Police Violence Against Black Women AND WOMEN OF COLOR 121 (2017) [hereinafter RITCHIE, INVISIBLE].]

151. See Trombadore, supra note 20, at 170 ("Structural barriers and vague descriptions are not the only factors that render [PSM] a hidden phenomenon; much of the difficulty in studying this problem stems from a lack of convention of what constitutes officer-involved sexual misconduct.").

152. See RITCHIE, INVISIBLE supra note 150 , at 105 (detailing a story about a woman in a postKatrina New Orleans workshop who never told anyone about her PSV story until that workshopfourteen years after the assault-because she said she had never "heard anyone talk about sexual violence as part of the fabric of police violence, or about police as perpetrators of sexual violence"); see also Alexandra Brodsky, "Rape-Adjacent": Imagining Legal Responses to Nonconsensual Condom Removal, 32 COLUM. J. GENDER \& L. 183, 184 (2017) (explaining that stealthing victims did not know how to describe their stealthing experience because the sexual violence did not have a specific name); Jenavieve Hatch, Victims of Stealthing Open Up About Why It's So Damaging, HuFFPoST (May 5, 2018), https://www.huffingtonpost.com/entry/victims-of-stealthing-open-up-about-why-its-sodamaging_us_59134ad1e4b0a58297e1ad88 [https://perma.cc/HN48-37FB] (quoting a stealthing survivor that stated "I was such a silly young girl at the time [of my stealthing experience], I really put all the blame on myself for making a terrible choice in a partner. Now that I have read a few articles on the apparent frequency of this happening to women, I think my mind is changing a bit').

153. See The Project, POLICE USE OF FORCE PROJECT, http://useofforceproject.org/\#review [https://perma.cc/6MHJ-JZ26] (explaining that most police departments have use of force policies even though most policies lack basic protections). 
such as "police brutality" and "excessive use of force" obscures that PSV is a natural extension of societal sexual violence. ${ }^{154}$

The silence surrounding PSV also helps to distort the prevalence of the offense. In her famous book, Invisible No More, Ritchie poses an interesting question: "What is the first image that comes to your mind when I say police brutality?" 155 The question is answered almost exactly the same way every time she asks it- "a [W] hite cop beating a Black man (almost always imagined as heterosexual and cisgender) with a baton." 156 Hardly ever, Ritchie reports, has the response been sexual violence. If it ever comes up, people usually discuss Abner Louima's case. ${ }^{157}$ The phrase "police brutality" almost never incites thoughts or discussions about women of color being sexually abused, harassed, or violated by police. ${ }^{158}$ Ritchie speculated that the absence of women of color in discussions of police brutality may be "merely one strand in a seamless web of daily gendered/racialized assaults by both state and private actors, unworthy of the focused attention commanded by police brutality against men of color perceived as a 'direct' form of state violence." 159

As discussion progresses, even more of a paradox emerges. An initial inquiry about police brutality almost never brings PSV to mind. Once Ritchie frames PSV as a form of "police brutality," however, she reports that at least one person has a PSV experience to share, usually one that has never been shared with anyone before. ${ }^{160}$ Ritchie's experiences highlight that once PSV is given a uniform definition and a national platform by police departments nationwide, victims will be more likely to talk about their experiences with PSV rather than conceal their trauma. ${ }^{161}$

A second major consequence of inconsistent or absent police department policies is that minimizing discipline allows officers to offend again. Commentators have frequently criticized a practice known as the "officer shuffle," where a police officer found guilty of misconduct is sent to another jurisdiction rather than dismissed from the police force entirely. ${ }^{162}$ Police officers

154. See RitchIE, INVISIBLE, supra note 150, at 104; see also Andrea J. Ritchie, Law Enforcement Violence Against Women of Color, in COLOR OF VIOLENCE: THE INCITE! ANTHOLOGY 138, 139 (INCITE! Women of Color Against Violence eds., 2006) [hereinafter Ritchie, Law Enforcement].

155. RITCHIE, INVISIBLE, supra note 150, at 104.

156. Id.

157. See id.

158. See id.

159. Ritchie, Law Enforcement, supra note 154, at 141.

160. See RITCHIE, INVISIBLE, supra note 150, at 104-05 (detailing her experience during a workshop where she framed PSV as a police brutality issue and "a middle-aged Black woman stood up and told the group that she had been raped by a cop when she was fourteen years old but before that very moment had never spoken to anyone about it").

161. See id.

162. See Cara E. Rabe-Hemp \& Jeremy Braithwaite, An Exploration of Recidivism and the Officer Shuffle in Police Sexual Violence, 16 POLICE Q. 127, 137-38, 140-41 (2012) (noting that repeat 
suspected of misconduct are allowed to resign rather than face discipline, then given recommendations or references to assist them in securing employment in another department. ${ }^{163}$

The officer shuffle occurs (and is criticized) for many types of misconduct, but it can be particularly problematic in the context of PSV as studies show that sexual offenders tend to commit their crimes over and over. ${ }^{164}$ In general, sexual crimes have a high recidivism rate. ${ }^{165}$ For example, one study found that in the general population (not solely police officers), offenders who were not caught and prosecuted averaged more than five rapes. ${ }^{166}$ Data indicates that this holds true for police officers who commit sexual violence: one study found that approximately 40 percent of the analyzed incidents of PSV were committed by an officer with at least one prior incident of PSV. ${ }^{167}$ In the context of PSV, the officer shuffle only works to perpetuate more sexual violence against citizens.

The officer shuffle and the silence surrounding PSV present significant dangers for both victims and citizens in general. The lack of effective policies, or any policies at all, addressing PSV almost inevitably sends a message to police officers: sexual violence against a civilian in your custody may not be a crime, but even if it is, you will get away with it and even if you do not, you can simply transfer to another department and commit sexual assault once again. ${ }^{168}$

It is a bare minimum first step to make legally explicit that a civilian in police custody cannot consent to any sexual activity with a police officer. This formal legal change, however, is not enough. As the next Section will demonstrate, the systemic problem of PSV arises out of a culture of police selfprotection and hegemonic masculinity that will not be adequately addressed by a single change in the formal definition of consent and sexual assault in the context of police custody.

offender officers were more likely to have previously worked at another police station); see also Trombadore, supra note 20, at 167 ("Officer shuffle occurs when discredited officers move between departments despite allegations of misconduct.").

163. See Rabe-Hemp \& Braithwaite, supra note 162, at 141.

164. See RITCHIE, INVISIBLE, supra note 150, at 124 (expressing concern over the practice whereby a police office is caught committing PSV and is simply transferred to another jurisdiction).

165. See Child Sexual Abuse Statistics, DARKNESS TO LIGHT, https://www.d21.org/wpcontent/uploads/2017/01/all_statistics_20150619.pdf [https://perma.cc/86G2-Z4ST] ("Released rapists were found to be 10.5 times as likely as non-rapists to be re-arrested for rape.").

166. See 2 SeXual Violence \& AbuSE: An ENCYClopedia of PREVEntion, IMPACTS, AND RECOVERY 706 (Judy L. Postmus ed., 2013). ("Undetected rapists tend to be repeat offenders with one study reporting an average of more than five rapes for offenders who never were prosecuted by the criminal justice system.”).

167. See Rabe-Hemp \& Braithwaite, supra note 162, at 136.

168. See SEXUAL VIOLENCE, supra note 166 ("[W]hen rapists are undetected[,] they skirt legal responsibility for their actions and any punishment that may have been handed down by the judicial system.”). 
II.

PSV, "Boys Will Be Boys," AND The Blue WaLl

As discussed above, some of the most challenging aspects of addressing PSV arise from how broadly PSV occurs and is tolerated, or at least ignored, by other police officers. PSV is not a problem of a few bad actors in the police. ${ }^{169}$ Instead, it is symptomatic of a broader cultural problem of how sexual violence and sexual coercion are viewed by police officers. Any comprehensive account of PSV must address this cultural problem directly.

One of the deepest running cultural tropes, reaching far beyond police officers, is the well-trod phrase "boys will be boys" - used to excuse all sorts of inappropriate and even criminal behavior. ${ }^{170}$ "Boys will be boys" is a harmful concept not simply because it excuses individual instances of bad behavior, but because it summarizes a belief that "boys are, by nature, disruptive, aggressive, unwise, and predatory." 171 This expression not only reinforces gender stereotypes (namely that men are masculine and aggressive) but also presumes that all men cannot control their destructive or aggressive behaviors. ${ }^{172}$ Such stereotypes are examined and helpfully explained by the concept of hegemonic masculinity.

\section{A. Hegemonic Masculinity}

The field of masculinities interrogates what expectations American society and law express about who men and boys are supposed to be. The field is generally labeled "masculinities" to indicate that there are different kinds of masculinity embodied by individual people. ${ }^{173}$ A key concept that directly challenges the myriad types of masculinities, however, is hegemonic masculinity: a single vision of masculinity that is seen as correct. This type of masculinity is described as the "ideal masculinity that has the most power at any

169. See Thomas Barker, Peer Group Support for Police Occupational Deviance, 15 CRIMINOLOGY 353, 354 (1977) (finding "little support" for the "myth of the rotten apple"); Timothy M. Maher, Police Chiefs' Views on Police Sexual Misconduct, 9 POLICE PRAC. \& RES. 239, 239-40 (2008) (describing the "'bad apple' theory of police corruption" as "subject to much criticism in recent years").

170. See Megan Garber, Brett Kavanaugh and the Revealing Logic of 'Boys Will Be Boys', ATLANTIC (Sept. 17, 2018), https://www.theatlantic.com/entertainment/archive/2018/09/brettkavanaugh-and-the-revealing-logic-of-boys-will-be-boys/570415/ [https://perma.cc/XGK3-SJ9R].

171. Rachel Brandt, 4 Ways the 'Boys Will Be Boys' Attitude Harms the Men in Our Lives, EVERYDAY FEMINISM (May 27, 2016), https://everydayfeminism.com/2016/05/boys-will-be-boysharm/ [https://perma.cc/T2UQ-JA9Z].

172. See Ann C. McGinley \& Frank Rudy Cooper, Identities Cubed: Perspectives on Multidimensional Masculinities Theory, 13 NEV. L.J. 326, 336-37 (2013) (explaining that the phrase "boys will be boys" excuses a man's excessively aggressive or destructive behaviors based on their biology rather than their social constructs and surroundings) [hereinafter McGinley \& Cooper, Identities Cubed].

173. See Richard Collier, Masculinities, Law, and Personal Life: Towards A New Framework for Understanding Men, Law, and Gender, 33 HARV. J. L. \& GENDER 431, 441 (2010); John M. Kang, The Burdens of Manliness, 33 HARV. J. L. \& GENDER 477, 495-507 (2010). 
given time and place." ${ }^{174}$ Hegemonic masculinity places itself firmly on top of a hierarchy, establishing the best and arguably only way to truly be a man. ${ }^{175}$ As Ann McGinley and Frank Rudy Cooper - two of the leading scholars in legal masculinities - have summarized, even though "the hegemony of men" acknowledges that on the whole American society is patriarchal, hegemonic masculinity recognizes the simultaneous "harm that socially constructed masculinity does to men."176

As implied by hegemonic masculinity's characterization as the only one way to be a man, its definition is extremely narrow. Hegemonic masculinity "focuses on competition, aggression, independence, control, and capacity for violence." ${ }^{\prime 177}$ Because masculinity is also intersectional, hegemonic masculinity usually describes "the upper middle class [W] hite male professional who represents the ideal version of masculinity because of the important relationship between masculinity and breadwinning." ${ }^{178}$ Hegemonic masculinity is thus raced, classed, and heteronormative as well as gendered.

This specific form of hegemonic masculinity obviously leaves out the majority of men. Additionally, hegemonic masculinity is fundamentally unstable: it is not a status, but a very temporary result of a successful performance of masculinity. ${ }^{179}$ Cooper describes hegemonic masculinity as both homosocial, meaning that the performances are for the benefit of other men, and anxious "that other men will unmask them as insufficiently manly." 180

Because of the pressure of attaining and re-attaining the narrow definition of hegemonic masculinity, as well as the intersectional dimensions that place many men further away from satisfying hegemonic masculinity's narrow strictures, many men feel as though reaching hegemonic masculinity is an impossible task. ${ }^{181}$ To prove their masculinity, these men tend to act in more physical, hypermasculine ways. ${ }^{182}$

Hypermasculinity is thus overcompensation. Denied the status of hegemonic masculinity for one reason, a man engages in hypermasculine

174. Ann C. McGinley, Policing and the Clash of Masculinities, 59 How. L.J. 221, 238 (2015) [hereinafter McGinley, Policing].

175. See Frank R. Cooper, "Who's the Man?": Masculinities Studies, Terry Stops, and Police Training, 18 COLUM. J. GENDER \& L. 671, 686 (2009) [hereinafter Cooper, Who's the Man].

176. McGinley \& Cooper, Identities Cubed, supra note 172, at 332; see also Nancy E. Dowd, Asking the Man Question: Masculinities Analysis and Feminist Theory, 33 HARV. J. L. \& GENDER 415, 418 (2010) [hereinafter Dowd, Asking the Man Question].

177. McGinley, Policing, supra note 174.

178. Id.

179. See Ann C. McGinley, Ricci v. Destefano: A Masculinities Theory Analysis, 33 HARV. J. L. \& GENDER 581, 586 (2010).

180. Cooper, Who's the Man, supra note 175, at 688; see also Frank Rudy Cooper, Masculinities, Post-Racialism and the Gates Controversy: The False Equivalence Between Officer and Civilian, 11 NEV. L.J. 1, 18 (2010) [hereinafter Cooper, Masculinities]; Nancy E. Dowd, Masculinities and Feminist Legal Theory, 23 WIS. J.L. GENDER \& SOC'Y 201, 210 (2008).

181. See McGinley, Policing, supra note 174, at 239.

182. See id. 
performance to try to make up the difference. ${ }^{183}$ Engaging in hypermasculine performance is, as Cooper put it, "an attempt to regain social status." 184 Hypermasculine performances often depend upon asserting one's dominance over people seen as "lesser" according to the strictures of hegemonic masculinity. ${ }^{185}$ Such performances include bragging about the sexual conquest of women and using physical aggression against people seen as weaker. ${ }^{186}$ Violence can be a key part of hypermasculine performances, particularly against people seen as potential threats to one's masculinity. ${ }^{187}$ Performances of hypermasculinity in attempts to impress or intimidate other men thus become part of the competition of hegemonic masculinity. ${ }^{188}$

\section{B. Police Culture and Masculinities}

Many of the more negative aspects of police culture are an example of such hypermasculine performances. In one of the foundational articles analyzing the police through a masculinities lens, Angela Harris contrasted the hypermasculinity of police with that of violent criminals:

The cultural image of a police officer is a uniquely valuable and rare kind of man: tough and violent, yet heroic, protective, and necessary to society's very survival. In a sense, the police officer is expected to be the mirror image of the paradigmatic criminal, the violent thug who threatens the lives and safety of innocent citizens. Criminals use violence in the service of evil; cops use violence to overcome evil. ${ }^{189}$

Police officers thus engage in the violence of hypermasculinity, but in a socially (and legally) acceptable way, justifying it as protection rather than danger. The job depends upon physical achievements and trust between police officers, "especially when they are in the wrong." 190

Police officers also come from communities that may be more likely to feel the need to engage in hypermasculine performances. One reason that a man fails to reach the top status of hegemonic masculinity is that he is not of sufficiently high socioeconomic class. ${ }^{191}$ Although being a police officer is itself a status

183. See Cooper, Who's the Man, supra note 175, at 691.

184. Id.; see also Angela P. Harris, Gender, Violence, Race, and Criminal Justice, 52 STAN. L. REV. 777, 785 (2000).

185. See id.

186. See Cooper, Who's the Man, supra note 175, at 691.

187. See Harris, supra note 184, at 781.

188. See Cooper, Who's the Man, supra note 175, at 688.

189. See Harris, supra note 184, at 793.

190. Leigh Goodmark, Hands Up at Home: Militarized Masculinity and Police Officers Who Commit Intimate Partner Abuse, 2015 B.Y.U. L. REV. 1183, 1210 (2015).

191. See McGinley, supra note 179, at 601 ("Firefighters also engage in subversive masculinities which highlight the firefighters' class-related attitudes toward other men. In particular, firefighters demean white collar men by disrespecting them. While the men in white collar jobs are more powerful economically, male firefighters gain their own power by questioning the masculinity of the male white collar workers and demonstrating their own superior strength."); Harris, supra note 184, at 783-84. 
boost of masculinity, the ranks of police officers disproportionately draw from lower socioeconomic statuses and the occupation of police officer is often considered a blue collar job. ${ }^{192}$ The employment base of the police is thus dominated by men who are most likely to feel that they must engage in hypermasculinity to assert their status.

Although police departments have increased the number of women officers in recent decades, they are still dominated by men. ${ }^{193}$ Police department cultures have problematic attitudes toward women that are consistent with hegemonic masculinity. ${ }^{194}$ Police departments have faced repeated issues with sexual harassment of female police officers by their coworkers ${ }^{195}$ as well as domestic violence committed against girlfriends and wives at home. ${ }^{196}$ The culture of police training uses female students in police academies as foils to define even more clearly in-groups of men and out-groups of everyone else. ${ }^{197}$ Police officers are also more likely than members of the public to believe problematic stereotypes about female victims of sexual assault. As Cory Rayburn Yung has detailed, "seventy-nine percent agree that "many women secretly wish to be raped' and sixty-five percent agree that women with 'bad reputations' make the most rape complaints." 198

Police officers and police departments then build a culture of support and silence on top of a foundation of hegemonic masculinity and hypermasculine performance. Scholars have described police departments as "closed groups" that develop their own unwritten rules of behavior. ${ }^{199}$ One of the most infamous examples is the notorious "blue wall of silence." 200 The blue wall is an unwritten police code of silence that demands that police officers remain silent or even affirmatively lie to conceal misconduct by a fellow officer. ${ }^{201}$ The blue wall, which "spawns a strong loyalty on the part of police officers to each other," 202 is believed to have developed as a result of the danger and hierarchical authority to

192. See Harris, supra note 184, at 794.

193. Cf. Dowd, Asking the Man Question, supra note 176, at 422 (describing masculinities as an attempt to "see gender where it is obvious, and to notice the difference between how gender operates in homosocial or male-exclusive or male-dominant environments, as compared to how gender functions in mixed gender environments").

194. See Goodmark, supra note 190, at 1212.

195. See Harris, supra note 184, at 795-96.

196. See Goodmark, supra note 190, at 1189-95.

197. See Anastasia Prokos \& Irene Padavic, 'There Oughtta Be a Law Against Bitches': Masculinity Lessons in Police Academy Training, 9 GENDER, WORK \& ORG. 439, 441 (2002).

198. Corey Rayburn Yung, Rape Law Gatekeeping, 58 B.C. L. REV. 205, 210 (2017)

199. Gabriel J. Chin \& Scott C. Wells, The "Blue Wall of Silence" as Evidence of Bias and Motive to Lie: A New Approach to Police Perjury, 59 U. PITT. L. REV. 233, 250 (1998).

200. Id. at 237 (defining the "blue wall of silence" as "an unwritten code in many departments which prohibits disclosing perjury or other misconduct by fellow officers, or even testifying truthfully if the facts would implicate the conduct of a fellow officer").

201. See id.

202. Id. at 252 . 
which police officers are subjected. ${ }^{203}$ Police officers face very serious physical danger in the line of duty, and trust between fellow officers takes on greater significance (and greater consequences) than almost any other coworking relationship.

William Westley's famous research published in the 1950s describes how secrecy "functions as a social bond among the police, by giving them something in common (if only a sense of mutual incrimination)." ${ }^{204}$ Additionally, police officers operate within a system of clearly delineated ranks, and obeying orders issued by higher ranking officers is a similarly essential component of maintaining safety amidst potentially dangerous activities. It is thus unsurprising that police officers develop such strong loyalties to fellow officers. ${ }^{205}$ Scholars note that the blue wall may also be a result of pressures on police officers from the public and the media not only to provide protection to the community but also to remain honest and trustworthy. ${ }^{206}$

While loyalty to one's coworkers is obviously not in and of itself corrupt, the nature of police work creates a unique type of group loyalty whereby police officers are mandated to maintain their allegiance even to corrupt police officers. ${ }^{207}$ This unwavering commitment to loyalty has harsh consequences. Police officers that breach the blue wall may be "ostracized and harassed[,] become targets of complaints and even physical threats[,] and are made to fear that they will be left alone on the streets in a time of crisis." ${ }^{208}$ Fearing these consequences, police officers tend to overlook peer misconduct or even lie about it. ${ }^{209}$ Even a generally honest police officer may feel pressured to maintain silence "in the face of another's misconduct." 210 Some police officers have indicated that they are more reluctant to report a police officer than a regular citizen because they "do not want to be responsible for getting a fellow cop in trouble." 211 Therefore, especially in cases alleging use of excessive force or

203. Id. at 237

204. William A. Westley, Secrecy and the Police, 23 SOC. FORCES 254, 256 (1956).

205. See Jerome H. Skolnick \& James J. Fyfe, Above the Law: Police and the EXCESSIVE USE OF FORCE 92 (1993).

206. Chin \& Wells, supra note 199, at 251.

207. Id. at 252-53; see also Westley, supra note 204 ("Secrecy stands as a shield against the attacks of the outside world; against bad newspaper publicity which would lower the reputation of the police; against public criticism from which the police feel that they suffer too much; against the criminal who is eager to know the moves of the police; against the law which the police all too frequently abrogate.").

208. Chin \& Wells, supra note 199, at 254; see also Maher, supra note 141, at 371 ("“I]t could mean suffering the consequences of sanctions by police coworkers.").

209. Chin \& Wells, supra note 199, at 254.

210. Id. at 251.

211. Maher, supra note 141, at 376. 
police brutality, police officers often come together to either conceal or justify a fellow officer's wrongful conduct. ${ }^{212}$

Additionally, the close bonds between police officers reinforce the vulnerability that can trigger hypermasculine performances. Two central commandments of hegemonic masculinity are not to be a woman and not to be gay. ${ }^{213}$ The close relationships between police officers, both emotional and physical, could easily be viewed as becoming romantic or even sexual. ${ }^{214}$ The trust and reliance among male police officers thus pushes them towards a perceived need to counter implications of being gay with hypermasculinity.

The blue wall also contributes to a relativist moral code that does not perceive incidents of PSV as morally wrong. In September 2008, researcher and former police officer Timothy Maher interviewed police chiefs in fourteen different police agencies located in the St. Louis metropolitan area about their perceptions regarding the nature, extent, and causes of PSV. ${ }^{215}$ Maher determined that four factors were particularly influential in allowing PSV: police culture, police departments' policies addressing PSV, opportunity for sexual violence, and lack of knowledge about PSV. ${ }^{216}$ Maher concluded that police culture, including the blue wall, creates an atmosphere of ethical relativism. ${ }^{217}$ Ethical relativism is a theory that suggests that morality is determined by "cultural traditions and socialization" rather than objective moral truths. ${ }^{218}$ In other words, one determines what is ethical and moral based on their social and cultural surroundings. ${ }^{219}$ Police officers thus create an understanding of morality and ethics as determined by police culture, which has deep roots in hegemonic masculinity.

The blue wall theory helps explain why some police officers conclude that PSV is not a moral or ethical failing that is worthy of attention. Maher's research concluded that 36.5 percent of police officers in the study have committed some form of PSV. ${ }^{220}$ This finding is staggering. It contradicts any notion that PSV is

212. See id. Notably, a study conducted by the International Association of Police Chiefs, which surveyed hundreds of police officers in twenty-one states, revealed that almost half of the officers stated that "the code [of silence] was strongest when excessive force was used." See Earl Ofari Hutchinson, It's Time for Cops to Break the Blue Code of Silence, HufFPost (Sept. 24, 2016), https://www.huffingtonpost.com/earl-ofari-hutchinson/its-time-for-cops-to-brea_b_12173778.html [https://perma.cc/4KQK-KZTY]. For an in-depth discussion about the blue wall of silence and police perjury, see Chin \& Wells, supra note 199.

213. See Michael S. Kimmel, Masculinity as Homophobia: Fear, Shame, and Silence in the Construction of Gender Identity, in TOWARD A NEW PSYCHOLOGY OF GENDER, 223, 229-31, 232-35 (Mary M. Gergen \& Sara N. Davis eds., 1997); see also Dara E. Purvis, Trump, Gender Rebels, and Masculinities, 54 WAKE FOREST L. REV. 423, 429-31 (2019).

214. See Harris, supra note 184, at 787-88.

215. Maher, supra note 141, at 355.

216. See id. at 376-78.

217. Id. at 375 .

218. Id. at 376 .

219. See id.

220. Id. at 367 . 
committed by a few bad actors and demonstrates not only the severity and widespread nature of PSV but also that police officers fail to grasp how widespread the offense is. ${ }^{221}$ The prevalence of PSV coupled with the theory of ethical relativism suggests that PSV is a behavior police officers have simply been conditioned to accept. ${ }^{222}$

The blue wall coupled with the theory of ethical relativism allows police departments to keep PSV under wraps. During Maher's study, one officer reportedly stated, "Everybody knows [PSM] goes on, but nobody makes a big deal. Not until some citizen reports it, or the media gets a hold of it will PSM become a hot issue." 223

Moreover, hegemonic masculinity helps explain why police officers often target people in the criminalized margins of society. ${ }^{224}$ Police officers looking to establish their masculinity will assert dominance over individuals lower in the identity hierarchy or individuals who are particularly vulnerable to the criminal justice system. ${ }^{225}$ Victims of PSV often include drug addicts, sex workers, LGBTQ+ people, and - disproportionately so-women of color. ${ }^{226}$ Notably, all of these groups occupy a lower level on the identity hierarchy of hegemonic masculinity than a police officer does. ${ }^{227}$ Unsurprisingly then, hypermasculine police officers are more likely to sexually assault members of these vulnerable groups in order to assert their dominance and establish their masculinity. ${ }^{228}$

Finally, hegemonic masculinity helps explain the fraught relationship that police officers often have with the community in which they serve. Many scholars have written about the epidemic of police violence against Black men and communities, a phenomenon Devon Carbado has called "blue-on-[B]lack violence." 229 Although some of the cause certainly traces back to white supremacy, masculinity, and a broader sense of "us versus them" also contribute. Ann McGinley described police killings of Black men, largely by White officers, as gendered violence. As she describes it, hypermasculine police officers must dominate civilians in their patrol areas, and violence inflicted on those civilians is one of the most effective ways to achieve that masculine dominance. ${ }^{230}$

221. Id. at 370 .

222. Id. at 371 ("Although peer pressure to actively engage in PSM may be perceived as low, the police culture may create an atmosphere in which officers are conditioned to be apathetic toward PSM, even if they themselves do not participate.").

223. Id. at 373 .

224. See Trombadore, supra note 20, at 165-67 (explaining that offending police prey on "vulnerable" communities that are unlikely to be believed if they try to press charges against the police for sexual assault).

225. See Cooper, Who's the Man, supra note 175, at 689.

226. See Trombadore, supra note 20, at 168.

227. See Cooper, Who's the Man, supra note 175, at 691-92.

228. See id. at 692 ("We might say that such hypermasculine behaviors are both a product of the existence of a normative masculinity and themselves a dominant way in which working-class men seek to establish their masculinity.").

229. Carbado, supra note 27, at 1480-81.

230. See McGinley, Policing, supra note 177, at 244. 
Cooper has a specific term for individual conflicts between a police officer and a member of the public: masculinity contests. A masculinity contest begins with Cooper's concept of the "command presence" of police officers projecting an "aura of confidence." 231 The flip side of the command presence of police officers is the expectation that civilians defer to police officers, showing respect for their greater authority. ${ }^{232} \mathrm{~A}$ masculinity contest, just as it sounds, is when two men attempt to assert their masculine power over the other, each attempting to prove his greater masculine status. ${ }^{233}$ In interactions between police and members of the public, masculinity contests can arise when a police officer deploys his command presence for no reason or if a member of the public does not show what the police officer considers to be appropriate deference. ${ }^{234}$

Cooper argued that stop-and-frisk interactions, known as Terry stops, are opportunities for police officers to stage and win a masculinity contest as they deploy both individual and institutional power to demand obedience from a civilian. ${ }^{235}$ A recent article echoed Cooper's argument, revisiting the impact of Terry stops in the era of \#MeToo and examining the often sexualized nature of frisks. ${ }^{236}$ Cooper has also written of the peril of a masculinity challenge when one's masculinity is threatened by a specific challenge or an inability to adequately perform masculinity. ${ }^{237}$ Cooper argued that masculinity challenges can be sparked by compensatory subordination: a man who lacks status in one characteristic finds another characteristic through which he can engage in a masculinity contest to prove his superiority. This may occur, for example, when a police officer with low socioeconomic status uses the power of his employment to dominate another man. ${ }^{238}$

Importantly, Cooper's reading of interactions between police officers and the public implies how and why police officers could inflict PSV as a masculinity contest. One implication has to do with the dominance of the individual victim, a masculinity contest won through sexual conquest. Moreover, if the unwritten rule of civilian interactions with police is that the civilian must defer to the police officer, then this unwritten rule underscores that any purported expressed consent granted by a member of the public could not be meaningful consent.

A broader implication, however, concerns the larger community. A successful hegemonic man accrues possessions - as Cooper puts it, "The indicia of manhood - money, power, women, and so on—are scarce resources; you can

231. Cooper, Who's the Man, supra note 175, at 694.

232. Cooper, Masculinities, supra note 180, at 19.

233. Id. at 21; see also id. at 23-29 (describing the arrest of Harvard Professor Henry Louis Gates at his own home as the product of a masculinity contest).

234. See id. at 19-22.

235. Cooper, Who's the Man, supra note 175, at 700.

236. See Josephine Ross, What the \#MeToo Campaign Teaches About Stop and Frisk, 54 IDAHO L. REV. 543 (2018).

237. Cooper, Masculinities, supra note 180, at 20.

238. Id. at $21-22$. 
always have more, and they gain their value from the fact that other men are denied them." 239 In masculinity contests between police officers and male members of the public, female members of the public are possessions that shift the balance of power in a police officer's favor if he takes them. In other words, the sexual domination of women in a community also becomes a mechanism of expressing masculine dominance over the men of that community. This is obviously a deeply problematic calculus but one that fits perfectly within the worldview of hegemonic masculinity.

Masculinities helps to deepen and explain what otherwise seems like inexplicable behavior by police officers who devote their lives to serving the public. Police officers are steeped in an environment of hegemonic masculinity, coding their job as essentially masculine and glorifying methods by which police officers demonstrate power over members of the public. Police officers therefore learn to engage in hypermasculine performances such as exerting sexual dominance and bragging about PSV behavior to their coworkers. ${ }^{240}$ Even if police officers inform their coworkers of this wrongful behavior, offending officers are rarely reprimanded because of ethical relativism and the blue wall. The officers' coworkers are conditioned to feel apathetic towards the wrongful behavior, and the blue wall dissuades them from reporting it, even if coworkers understand the severity of the behavior. ${ }^{241}$ Thus, the blue wall protects offending officers despite their egregious conduct. Police culture perfectly embodies a "boys will be boys" attitude, giving male officers a pass to sexually assault women (and other minority groups) without facing any consequences. ${ }^{242}$ The structure of hegemonic masculinity both makes such violence more likely and prevents police departments from meaningfully addressing it.

III.

\section{A SYSTEMIC PROBLEM DEMANDS SYSTEMIC REFORM}

Despite statistics indicating that a police officer engages in PSV every five days, ${ }^{243}$ PSV remains a deeply systemic problem that is underreported, underresearched, and underdiscussed. Remaining silent about conduct that both jeopardizes the integrity of the criminal justice system and endangers women undermines the work of sexual assault advocates around the world. Therefore, in

239. Cooper, Who's the Man, supra note 175, at 688.

240. See Yoder, supra note 64. In an interview for the online article, Penny Harrington stated: It's a minority of officers who do this kind of thing ... [but] there is this culture in law enforcement ... you don't tell on your buddies, and you become so insular and isolated. You get so bought into this police culture - this macho, very often sexualized culture - and you don't see anything wrong with it. It's like ... a badge of honor, how many women in the Id. community you can have sex with, and the younger the better.

241. See id.

242. See Maher, supra note 141, at 373 (explaining that one of the police officers interviewed for the study stated, "Cops are just like all men," which only serves to perpetuate gender stereotypes).

243. Trombadore, supra note 20, at 160 (citing Spina, supra note 49). 
an effort to expand sexual assault awareness through movements like \#MeToo, PSV must be included in the dialogue surrounding sexual assault. Simultaneously, PSV should be incorporated into broader discussions of police brutality as it is one form of violence inflicted on both individuals and entire communities.

As other scholars have argued, a necessary preliminary step in addressing PSV is developing a uniform definition of PSV. ${ }^{244} \mathrm{~A}$ uniform definition of PSV would provide a clear legal standard for courts and law enforcement and would appropriately label the term for the general public. ${ }^{245}$ For example, in 1979, Catharine MacKinnon formally defined workplace harassment as "sexual harassment." 246 Once the legal term was defined, capturing what had otherwise seemed like a broad and varied problem, awareness of the problem skyrocketed. ${ }^{247}$ In 2003, Congress passed the Prison Rape Elimination Act $^{248}$ after stakeholders began defining and raising awareness of sexual misconduct between corrections officers and inmates. ${ }^{249}$ Most recently, in 2016, Alexandra Brodsky coined the term "stealthing," a form of sexual assault whereby a man takes off his condom without his partner's consent. Once stealthing was openly discussed, victims recognized the sense of betrayal they harbored was warranted. ${ }^{250}$ These examples illustrate that "unity in problem formulation has the potential to mobilize entire movements." 251

Therefore, to ensure accountability and raise awareness about PSV, a uniform definition of PSV must be adopted. ${ }^{252}$ Defining PSV will assist the public in conceptualizing the behavior and will also set precise boundaries for police officers and administrators. ${ }^{253}$ Until the behavior is specifically and uniformly defined, statistics will not be entirely accurate and awareness of the problem will be limited to those who actively research PSV. A uniform definition of PSV will help mobilize a movement that should have begun years ago. ${ }^{254}$

Merely defining the offense, however, is not enough. PSV is a problem emerging from deep roots embedded in police policies and culture. A systemic

244. See Trombadore, supra note 20, at 163 ("Because scholars and reporters rarely define [PSM], the various manifestations included in descriptions of this behavior cause confusion among stakeholders.").

245. Id. at 175 .

246. See id. at 176.

247. Id.

248. 34 U.S.C. $\$ 30302$ (2018)

249. See Trombadore, supra note 20, at 178-79.

250. See Brodsky, supra note 152, at 183; see also Melissa Marie Blanco, Sex Trend or Sexual Assault?: The Dangers of "Stealthing" and the Concept of Conditional Consent, 123 PENN ST. L. REV. 217 (2018).

251. Trombadore, supra note 20, at 175.

252. See id. at 170.

253. See Maher, supra note 141 , at 377.

254. See Trombadore, supra note 20, at 175. 
response is necessary to address the effects, the concealment, and the cultural roots of PSV.

\section{A. The Substance of PSV: Custody and Consent}

About thirty states do not currently have laws prohibiting police officers from having "consensual" sex with people in their custody. ${ }^{255}$ This is an unacceptable lapse in regulation: it should be legally impossible for a civilian in custody to consent to sexual contact with a police officer. Establishing a brightline rule forbidding sexual contact between a police officer on duty and a member of the public must be the first step in addressing PSV.

As an initial matter, it is important to discuss the use of the concept of custody. As discussed above, state statutes that prohibit PSV generally prohibit sexual contact between a police officer and a person in police custody. In theory, "in custody" does not mean that a person has actually been arrested or formally taken into custody. In Miranda v. Arizona, ${ }^{256}$ the Supreme Court of the United States held that a person is considered "in custody" not only when they are physically taken into custody, but also if they are otherwise deprived of freedom of action in any significant way. ${ }^{257}$

In subsequent cases, however, the Supreme Court has held that a person is not in custody for Miranda purposes even in contexts where most people would not feel free to leave. For example, the Court has held that routine traffic stops do not require a Miranda warning. ${ }^{258}$ This is true even though, as the Court acknowledged, most states make it a crime to refuse to stop upon a police officer's signal or, once stopped, to drive away before the police officer gives permission. ${ }^{259}$ The Court reasoned that, in contrast to being individually pulled over, a routine traffic stop is more akin to a Terry stop, in which a police officer briefly detains a person who the officer has reasonable suspicion is involved in the commission of a crime. ${ }^{260}$ The Court described both stops as "comparatively nonthreatening ... detentions," that did not constitute a person being in custody for the purpose of a Miranda warning. ${ }^{261}$

This Miranda analysis intersects with a related question under the Fourth Amendment's protection against search and seizure. The Fourth Amendment requires reasonable suspicion before a person may be seized and searched. ${ }^{262}$ Even without reasonable suspicion, however, the police are free to search a person if the person voluntarily consents. In assessing whether a person

255. The variation in counting by different commentators is due to the wide variety in statutory language, as discussed above. See supra notes 32 and 33 and accompanying text.

256. 384 U.S. 436 (1966)

257. Id. at 444 .

258. Berkemer v. McCarty, 468 U.S. 420, 436-37 (1984).

259. See id. at 436.

260. See Terry v. Ohio, 392 U.S. 1, 26-27 (1968).

261. Berkemer, 468 U.S. at 440.

262. See Florida v. Bostick, 501 U.S. 429, 433-34 (1991). 
voluntarily consented to a search or whether the person had already been seized by the police, the Court posed a similar question: would a reasonable person have felt free to "terminate the encounter" with the police? ${ }^{263}$ If so, then they were not seized and could have told the officer not to search them.

This raises two dilemmas in the context of PSV. The first returns to the idea of consent. If a police officer asks to search a person, the voluntariness of that consent is evaluated by considering the totality of the circumstances. ${ }^{264}$ Consent may be valid even if the person later says they did not know they could refuse ${ }^{265}$ or had already been arrested. ${ }^{266}$

One parallel question in the context of PSV is: if a person can consent to a search by the police, shouldn't a person also be able to consent to sexual activity with the police? The answer is no, not only for the reasons discussed earlier focusing on the validity of an individual's consent, but also from the perspective of the police. The search of a member of the public furthers "the effective enforcement of criminal laws." ${ }^{267}$ Evaluating how protective the Constitution requires police to be of a civilian's choice to consent to a search thus balances an individual's liberty rights against the whole community's security. ${ }^{268}$

By contrast, civil consent to a sexual encounter with a police officer has no such value. There are almost no circumstances in which police sexual interactions with civilians are necessary (or even relevant) for a valid law enforcement purpose. ${ }^{269}$ A police search of a suspect furthers the core goals of law enforcement so courts have found an acceptable margin of error allowing the search even where the civilian claims their consent was not voluntary. Without any purpose but the sexual gratification of the police officer, there is no reason why any margin of error should be tolerated.

This reasoning illuminates the second dilemma: do current statutes focusing on custody go far enough? It is obvious why a person in custody cannot consent to sexual acts with a police officer. Given that, by definition, a person "in custody" feels they are not at liberty to even terminate their conversation with the police officer, purportedly consenting to sexual activities with that same

263. United States v. Drayton, 536 U.S. 194, 195 (2002).

264. See Schneckloth v. Bustamonte, 412 U.S. 218, 227 (1973).

265. See id. at 231-33.

266. See United States v. Watson, 423 U.S. 411, 424-45 (1976).

267. Schneckloth, 412 U.S. at 225.

268. See id.

269. The obvious exception is operations investigating sex workers in which police officers working undercover pose as clients of the sex workers. Although courts have occasionally found that a police officer's actions were so outrageous as to violate due process, scholars have criticized tacit acceptance of at least some sexual interactions in the context of undercover operations. See State v. Burkland, 775 N.W.2d 372, 375-76 (Minn. Ct. App. 2009) (finding that initiating sexual contact during a massage was outrageous); Phillip Walters, “Would A Cop Do This?": Ending the Practice of Sexual Sampling in Prostitution Stings, 29 LAW \& INEQ. 451, 462-65 (2011) (listing examples of sexual contact between police officers and members of the public that were not found to be outrageous). 
police officer is entirely implausible. ${ }^{270}$ The bare minimum, therefore, is that a uniform definition of PSV in all fifty states must incorporate the substantive rule that a person in police custody is incapable of consenting to sexual activity with a police officer. New York's statute, passed in the wake of the Anna Chambers incident, is a good example of such a law:

A person is deemed incapable of consent when he or she is: ... (j) detained or otherwise in the custody of a police officer, peace officer, or other law enforcement official and the actor is a police officer, peace officer or other law enforcement official who either: (i) is detaining or maintaining custody of such person; or (ii) knows, or reasonably should know, that at the time of the offense, such person was detained or in custody. ${ }^{271}$

Even this rule, however, would not reach conduct such as Holtzclaw's sexual assault of a seventeen-year-old girl after driving her home. ${ }^{272}$ Andrea Ritchie proposed a much broader rule prohibiting sexual activity while a police officer is on duty, using a police vehicle, or at a state facility. ${ }^{273}$ Colorado's statute takes a similarly broad perspective in its statute defining unlawful sexual conduct by a peace officer:

(1) A peace officer commits unlawful sexual conduct by a peace officer by knowingly engaging in sexual contact, sexual intrusion, or sexual penetration under any of the following circumstances:

(a) In the same encounter, the peace officer contacts the victim for the purpose of law enforcement or contacts the victim in the exercise of the officer's employment activities or duties;

(b) The peace officer knows that the victim is, or causes the victim to believe that he or she is, the subject of an active investigation, and the peace officer uses that knowledge to further the sexual contact, intrusion, or penetration; or

(c) In furtherance of sexual contact, intrusion, or penetration, the peace officer makes any show of real or apparent authority. ${ }^{274}$

This Article focused on sexual contact with a person in custody because the legislative gap seems so obviously deficient, particularly in contrast with formal prohibitions of sexual contact between corrections officers and people in prison. It is our opinion, however, that the broader approach, used by Colorado and proposed by Andrea Ritchie, focusing on use of a police officer's authority is a better approach. As discussed above, there is no legitimate reason why a police officer would use the power of their badge to engage in sexual contact with a member of the public. A clear prohibition of such coercion would be ideal, while

270. See Bodde \& Lorshbough, supra note 85 .

271. N.Y.PENAL LAW § 130.05(3)(j)(i)-(iii) (2019).

272. See supra notes $12-17$ and accompanying text.

273. James E. Copple \& Patricia M. Dunn, Gender, Sexuality, And 21St Century POLICING: PROTECTING THE RIGHTS OF THE LGBTQ+ COMMUNITY 46-55 (2017).

274. COLO. REV. StAT. ANN. § 18-3-405.7(1)(a)-(c) (2019) 
the more common approach of prohibiting sexual contact with individuals in custody would be a second-best option.

\section{B. Formalities of Fighting PSV}

A clear external rule will often not be enough to tackle PSV. In addition to the uniform substantive rule, clearer formal procedures should implement the rule within police departments and the larger community. ${ }^{275}$ Scholars indicate that police administrators play a crucial role in modifying police officer behavior. ${ }^{276}$ External rules of liability, even criminal liability, will not be enough. Given the "apparent availability of opportunities for misconduct provided by police work," police administrators are in a unique position to proactively control PSV. ${ }^{277}$ Furthermore, because of the ethical relativism operating within police departments, administrators must condition officers to recognize the dangerousness and severity of PSV. ${ }^{278}$

In order to most effectively dismantle PSV from the inside, administrators "should be educated and trained about sexual [violence] and its effects on policing." 279 Understanding some of the likely reasons PSV is prominent will allow police department administrators to create more effective policies grounded in research. Additionally, knowledge about PSV will allow police department administrators to communicate and emphasize that all PSV is problematic, not just the most severe forms. ${ }^{280}$ Finally, police department administrators are in the best position to advocate for the integrity of the criminal justice system, which is strongly undermined by PSV. ${ }^{281}$ Once "the secrecy surrounding PSM is removed, and police administrators, supervisors, and officers take this problem seriously, it is likely that the true extent of PSM will be discovered and legitimate efforts can be made to control it." ${ }^{282}$ Until then, however, the blue wall will continue protecting offending officers who abuse their authority by preying on the most vulnerable.

A key component of this administrative change is the need for police departments to adopt written policies defining and prohibiting PSV. The lack of written policies addressing PSV "may suggest that police officials believe that PSM is not a significant problem and therefore is not worthy of a policy." 283 Implementing formal policies addressing PSV may be instrumental in dismantling this behavior within police departments. At minimum, specific,

275. See Yung, supra note 198, at 239.

276. See Maher, supra note 141, at 378.

277. Id.

278. See supra notes 217-219 and accompanying text.

279. See Maher, supra note 141 , at 377.

280. See id. at 377.

281. See id. at 355 ("[PSM] compromises the integrity of the law enforcement community and interferes with police officers' ability to effectively perform their duties.").

282. Id. at 377 .

283. Id. at 378 . 
formal policies can clearly define what is expected of police officers and what is considered inappropriate conduct. Internal guidance from within the department will directly combat the ethical relativist perception that PSV is acceptable (or at least not worth reporting). ${ }^{284}$ In this way, police department policies can serve an expressive function: detailing explicit expectations which may serve both "to provide a voice in which citizens may speak and alter the behavior of people the [policies] address." 285 Policies addressing PSV would therefore "send a message to police officers and the public that this behavior is not condoned or tolerated." 286 Written policies addressing PSV may be a crucial tool for controlling police behavior, ${ }^{287}$ which is crucial given the severity and prevalence of PSV and the strength of the blue wall.

Research into other examples of police misconduct further substantiates the effectiveness of written policies. The Use of Force Project conducted research on police departments with "use of force" policies, investigating whether there was a relationship between use of force policies and the prevalence of police killings. ${ }^{288}$ Their research revealed that police departments with use of force policies had fewer killings per population and per arrest than those without. ${ }^{289}$ The advocates determined that "a police department with no... policies currently in place would have 72 [percent] fewer killings by implementing all ... of these policies." 290 The advocates concluded their research by stating:

This [research] suggests that advocacy efforts pushing police department[s] to adopt more restrictive use of force policies - and the accountability structures to enforce them - can substantially reduce the number of people killed by police in America. And while this analysis was limited to examining rates of deadly force, these policies may also be associated with reductions in other forms of police violence as well. ${ }^{291}$

Although the Use of Force Project relates only to use of deadly force, the research suggests that police department policies can be highly influential in controlling police behavior. ${ }^{292}$ Accordingly, all police departments in the United

284. See Carl E. Schneider, The Channeling Function of Family Law, 20 HOFSTRA L. REV. 495, 498 (1992).

285. Id.; see also ROBERT BELLAH, ET AL., THE GOOD SOCIETY 10 (2011) (explaining that laws have the ability to create societal expectations by enforcing positive and negative sanctions).

286. Maher, supra note 141, at 377.

287. Id. ("Some research suggests that policies help establish uniformity in policing and create a formal framework for controlling police behavior.").

288. Id.

289. See id.

290. See The Project, POLICE USE OF FORCE PROJECT, supra note 153.

291. Id.

292. It is of course possible that correlation is not causation and the presence of use of force policies reflects the culture of police departments that were already taking other measures to reduce the number of police-involved killings. The Use of Force Project acknowledges this limitation and calls for future research into causation but nonetheless concludes that the impact of use of force policies is clear enough to justify promoting adoption of such protections. See id. 
States should create and enforce policies addressing PSV to reduce the amount of people assaulted by police. To be most effective, the policies must expressly prohibit the "officer shuffle." Without a stipulation in the policies prohibiting the "officer shuffle," the policies will be lackluster and police officers will not take them seriously. ${ }^{293}$

Additionally, states and police departments should establish a clear method for members of the public to report misconduct by police, including PSV. Every state should institute a civilian complaint department similar to New York's Civilian Complaint Review Board. PSV victims are typically fearful of retaliation by the assaulting officer and often do not know where to report police misconduct. Creating a civilian complaint department where civilians can press charges against officers will alleviate that fear and ensure that victims do not suffer in silence simply because they are unsure of where to report. Creating and enforcing written policies addressing PSV will set a standard of intolerance of PSV within police departments which may in turn reduce the occurrence of PSV. Additionally, establishing separate entities to review and address PSV cases (and other forms of police violence) will ensure that police conduct is reviewed and that police authority is not abused. Thus, creating a separate entity to take care of police officer complaints will ensure that police officers and police departments are not "[l]eft unchecked." ${ }^{294}$

\section{Fighting the Culture of PSV}

Substantive and procedural changes within the law and police departments, however, are not enough. PSV is symptomatic of a broader cultural problem combining police brutality, hegemonic masculinity, and broader tensions implicating race, class, and other identities. Any attempt to meaningfully combat PSV must take these deeper roots into account.

\section{Call It What It Is: PSV Is a Form of Police Brutality}

If police brutality can take the form of sexual abuse, do our laws, police department policies, and media carve out a conceptual difference between traditional police brutality and PSV? It is unquestionably a good thing that public awareness of police brutality has risen in recent years. It is problematic, however, that the bulk of the attention has focused on police killings of Black men by White officers, overlooking other forms of violence. ${ }^{295}$

293. Maher, supra note 141, at 373 (identifying an interviewed officer that stated, "I guess it couldn't hurt to have a policy for PSM, but only if it is enforced. The department would have to make it clear that this type of thing is not tolerated and if you get caught, you get canned").

294. See Trombadore, supra note 20, at 165.

295. See Andrea J. Ritchie, \#sayhername: Racial Profiling and Police Violence Against Black Women, 41 HARBINGER 187, 190 (2016); Jasmine Sankofa, Mapping the Blank: Centering Black Women's Vulnerability to Police Sexual Violence to Upend Mainstream Police Reform, 59 How. L.J. 651, 656 (2016). 
PSV is also a form of police brutality and should be included in any discussion addressing police violence against the public. Categorizing PSV and police brutality separately perpetuates the notion that sexual assault of women of color and LGBTQ+ people by police officers is a less important problem than police violence against Black or African American men. By characterizing PSV differently than police brutality, the media, police departments, and legislatures "fail to understand sexual assault as structural violence that courts have not adequately protected against and the sinister history of policing and incarceration in this country. ${ }^{296}$ In order to acknowledge the extent of PSV and the dangers it poses to victims, law enforcement, and the integrity of the criminal justice system, dialogue about PSV must be reframed to capture that PSV is a subset of police brutality. Until the law, police departments, and the media recognize this, women - specifically women of color - will continue to be treated as secondclass citizens. Therefore, "[o]nly by inserting discussion of [PSV] into the dominant discourse surrounding police violence can we hope to eliminate the problem." ${ }^{297}$ Furthermore, this inclusion will enrich the broader discussion of police violence. We cannot fully grasp the problem of police brutality without acknowledging all forms of police brutality.

\section{Acknowledge PSV's Intersectionality}

Any discussion of PSV must expressly acknowledge the intersectional nature of the violence and victimology. Famously coined by Kimberlé Crenshaw, ${ }^{298}$ intersectionality recognizes multiple roots of oppression and discrimination that can operate simultaneously against a single person. In the Holtzclaw case, he almost exclusively targeted women of color who came from low socioeconomic backgrounds and had criminal histories. Each of those characteristics made them more vulnerable to his assault. The confluence of several characteristics meant that Holtzclaw identified his victims as unlikely to meaningfully fight back or report his crimes. As Devon Carbado described Holtzclaw's victimology:

The women whom Holtzclaw assaulted were bargaining in the shadow of their vulnerability and his power. That vulnerability and power derived from the presumptive legitimacy of police conduct, the invisibility of sexual assault as a form of police violence, the historical sexual inviolability of [B]lack women, and that these women were unlikely icons of victimization around whom the public at large or the [B]lack community specifically would organize. ${ }^{299}$

Just as PSV should be included in any discussion of police brutality, it should also be incorporated into any discussion of \#MeToo and sexual violence.

296. Sankofa, supra note 295 , at 657 .

297. Trombadore, supra note 20, at 159.

298. See Crenshaw, supra note 61.

299. Carbado, supra note 27, at 1500. 
It is particularly important, however, to acknowledge the profoundly intersectional victimology of PSV, especially when contrasted to high profile examples of assault that dominate headlines about \#MeToo, often involving affluent White women. Just as the picture of police brutality should be expanded beyond White officers killing Black men, the picture of sexual oppression should be expanded beyond White men assaulting White women.

\section{Changing Police Culture}

Finally, any discussion of PSV must address and combat police culture's hegemonic masculinity. One solution proposed by scholars such as Nancy Leong is a simple one: encourage police departments to recruit more female officers. Leong argues this would reduce incidents of excessive force against members of the public. ${ }^{300}$ At first blush, this may seem like a simplistic approach, but diversifying the police force helps disrupt at least some of the dominant messages and implicit cultural norms among police officers. ${ }^{301}$ Notably, any such efforts cannot simply emphasize gender neutrality in hiring. Rather, as Valorie Vojdik has advocated, any attempt to make police departments more gender-diverse should examine the causes of predominantly male police forces and address all of those causes, including both explicit policies and implicit norms. ${ }^{302}$

Second, discussions of police culture and interactions with the public, regardless of their gender, should take masculinities into account. "Boys will be boys" is a frequent phrase employed in discussions of misbehavior by the public and has garnered at least some public criticism. "Men will be men," however, is a very different statement, and discussions of the role manliness and masculinity play in police brutality has been insufficiently incorporated into public discussion.

Third, policy-makers should ask what measures might disrupt operation of hegemonic masculinity within police departments. One intriguing and counterintuitive possibility is to raise the social status of police officers by increasing their salaries. Although this may seem like an odd response to an issue of police misconduct, Monica Bell identified the low wages of police officers as one reason poor communities are deprived of meaningful protection and feel legal estrangement from the police. ${ }^{303}$ Professor Bell's argument that poor communities would more likely receive the benefits of police protection if police wages reflected their value in the community also extends to PSV. Masculinities

300. See Nancy Leong, In A Different Force, 86 GEO. WASH. L. REV. 1552, 1552 (2018).

301. Cf. JAMES FORMAN, JR., LOCKING UP OUR OWN: CRIME AND PUNISHMENT IN BLACK AMERICA (2017) (discussing how and why Black representatives and law enforcement supported policies with disproportionate effects on Black communities).

302. See Valorie K. Vojdik, Gender Outlaws: Challenging Masculinity in Traditionally Male Institutions, 17 BERKELEY WOMEN'S L.J. 68, 74 (2002).

303. See Monica C. Bell, Police Reform and the Dismantling of Legal Estrangement, 126 Y ALE L.J. 2054, 2131-36 (2017). 
buttresses this argument further, as raising the socioeconomic status of police officers could reduce the perceived need to raise one's status through hypermasculine performance.

Finally, the role of the blue wall in police departments' masculine culture must be addressed. Because of the blue wall, offending police officers are often protected from any consequences. Even police officers who do not condone PSV are nonetheless silent about the issue in the name of loyalty to the brotherhood. ${ }^{304}$ Accordingly, the blue wall perpetuates the idea that police officers can sexually assault vulnerable people without fear of expulsion from the police force. The only way to eliminate the problem is to reduce the effectiveness and protection of the blue wall. While the blue wall has existed for centuries and undermining its force will be extremely difficult, the only people who can dismantle the force of the blue wall are those whose interests it protects: police officials and administrators.

\section{CONCLUSION}

PSV is a deeply rooted problem with shocking prevalence across the country. Combating PSV will require meaningful legal and cultural changes to police departments. With a series of targeted reforms, however, such significant change is possible. Police departments and legislatures should create, adopt, and advocate for a uniform definition of PSV. Such a definition will help the public conceptualize the violence and understand the gravity of the problem. This uniform definition should establish that a person in police custody cannot consent to sexual activities with a police officer. Additionally, the media, police departments, and advocates should take measures to ensure PSV is categorized appropriately in the public eye, namely that PSV is a subset of police brutality that specifically targets vulnerable groups such as women, the LGBTQ+ community, socioeconomically disadvantaged people, and other marginalized demographics. This targeting happens as a result of a troubling trend towards privileging hegemonic masculinity within police culture.

Finally, because PSV appears to be, at least in large part, a result of the police atmosphere promulgated by ideas of hegemonic masculinity and unwavering loyalty, police administrators are in the best position to condemn PSV. To begin that movement, every police department across the nation should create and enforce policies specifically addressing PSV. These policies must specifically include a prohibition against the "officer shuffle," as a policy without an explicit prohibition will not adequately protect vulnerable people from PSV. Until these measures are taken, underreporting of PSV and incredibly rare individual proceedings will continue to be too little and too late.

304. See Chin \& Wells, supra note 199, at 251. 